University of Tennessee Health Science Center UTHSC Digital Commons

$12-2008$

\title{
The Role of FGF Signaling in Retinal Development
}

Abbie A. Hartge

University of Tennessee Health Science Center

Follow this and additional works at: https://dc.uthsc.edu/dissertations

Part of the Medical Biochemistry Commons, and the Medical Cell Biology Commons

\section{Recommended Citation}

Hartge, Abbie A. , "The Role of FGF Signaling in Retinal Development" (2008). Theses and Dissertations (ETD). Paper 343. http://dx.doi.org/10.21007/etd.cghs.2008.0128.

This Thesis is brought to you for free and open access by the College of Graduate Health Sciences at UTHSC Digital Commons. It has been accepted for inclusion in Theses and Dissertations (ETD) by an authorized administrator of UTHSC Digital Commons. For more information, please contact jwelch30@uthsc.edu. 


\title{
The Role of FGF Signaling in Retinal Development
}

\begin{abstract}
The development of the retina is a precise balance between intrinsic competence and extrinsic factors. This interplay is known to regulate the generation of cell types in the developing retina and similar mechanisms have been found in other regions of the CNS. In the developing retina, FGFs are a large family of secreted polypeptide growth factors. Fgf15 is the major Fgf expressed during retinal development in mice. Fgf15 is an example of an FGF that has been shown to control proliferation, cell fate specification, differentiation and migration during development. In this thesis I used analysis of specific genes throughout retinal development, as well as characterization of Fgf receptor mutant mice and Fgf15 knockout explant retina. The preliminary data presented evidence that Fgf15 is a good candidate for an extrinsic factor that may regulate retinal progenitor cell proliferation in the developing retina. When combined with the expression data, these findings suggest that in the absence of Fgf signaling, retinal progenitor cells fail to complete their normal developmental program.
\end{abstract}

\section{Document Type}

Thesis

Degree Name

Master of Science (MS)

Program

Biomedical Sciences

Research Advisor

Dr. Michael A. Dyer, Ph.D.

\section{Keywords}

Retina, Development, Proliferation, Fibroblast Growth Factor, Fgf15

Subject Categories

Medical Biochemistry | Medical Cell Biology | Medicine and Health Sciences 
THE ROLE OF FGF SIGNALING IN RETINAL DEVELOPMENT

\author{
A Thesis \\ Presented for \\ The Graduate Studies Council \\ The University of Tennessee \\ Health Science Center
}

\author{
In Partial Fulfillment \\ Of the Requirements for the Degree \\ Master of Science \\ From The University of Tennessee
}

By

Abbie A. Hartge

December 2008 


\begin{abstract}
The development of the retina is a precise balance between intrinsic competence and extrinsic factors. This interplay is known to regulate the generation of cell types in the developing retina and similar mechanisms have been found in other regions of the CNS. In the developing retina, FGFs are a large family of secreted polypeptide growth factors. Fgf15 is the major Fgf expressed during retinal development in mice. Fgf15 is an example of an FGF that has been shown to control proliferation, cell fate specification, differentiation and migration during development. In this thesis I used analysis of specific genes throughout retinal development, as well as characterization of Fgf receptor mutant mice and Fgf15 knockout explant retina. The preliminary data presented evidence that Fgf15 is a good candidate for an extrinsic factor that may regulate retinal progenitor cell proliferation in the developing retina. When combined with the expression data, these findings suggest that in the absence of Fgf signaling, retinal progenitor cells fail to complete their normal developmental program.
\end{abstract}


CHAPTER I. BACKGROUND AND SIGNIFICANCE . . . . . . 1

Anatomy of the retina . . . . . . . . . . . . . $\quad .1$

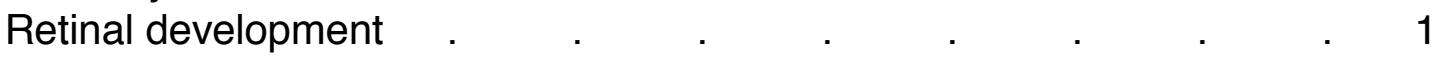

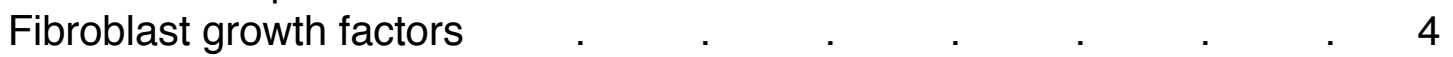

CHAPTER II: MATERIALS AND METHODS . $\quad$. $\quad$. $\quad$. $\quad$. 7

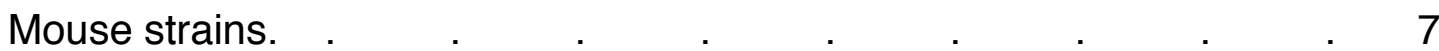

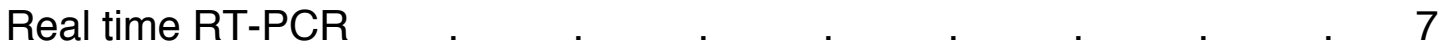

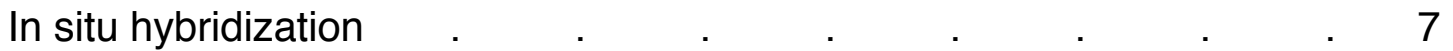

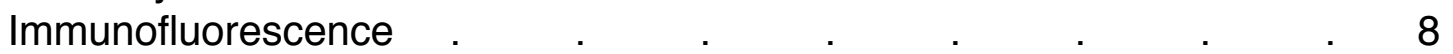

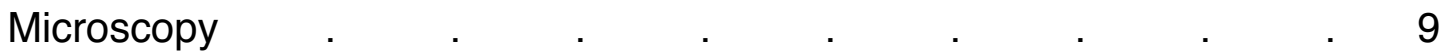

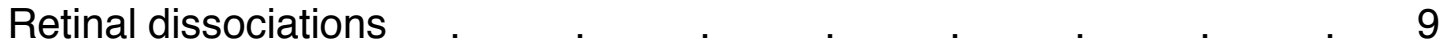

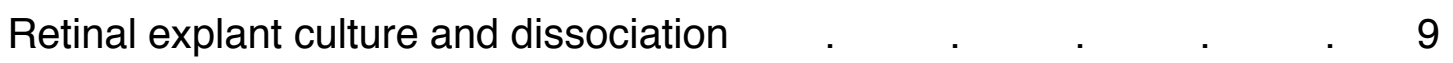

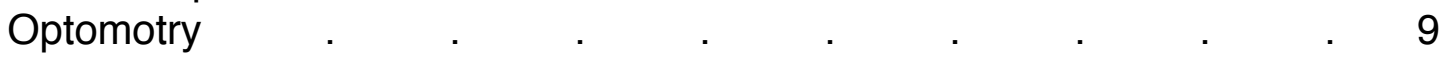

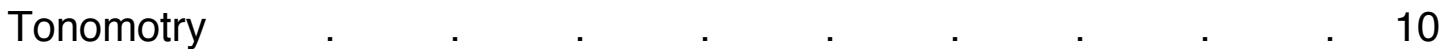

Transmission electron microscopy $\quad . \quad$. $\quad . \quad$. $\quad . \quad$. $\quad$. 10

CHAPTER III: EXPERIMENTAL RESULTS . . . . . . . . 11

Expression of Fgf15 and Fgfr genes in the developing retina . . 11

Characterization of Fgf15, Fgfr1-4 and Fgfrl1 expression vectors . . 18

Inactivation of Fgfr1-4 in the developing retina . . . . . 20

Visual acuity and intraocular pressure measurements of

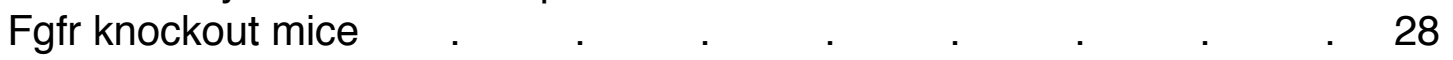

Characterization of Fgf15-deficient retinae . . . . . . . . 28

CHAPTER IV: DISCUSSION $\quad . \quad$. $\quad . \quad$. $\quad . \quad$. $\quad . \quad . \quad . \quad 37$

CHAPTER V: FUTURE DIRECTIONS . . . . . . . . . $\quad$. 39

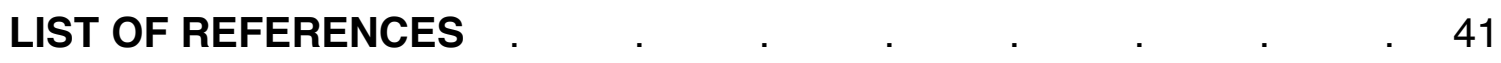

APPENDIX: CHAPTER III SUPPLEMENTARY INFORMATION . . 45

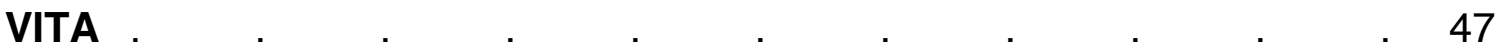




\section{LIST OF FIGURES}

Figure 1. Development of the mammalian retina $\quad . \quad$. $\quad$. $\quad$. 2

Figure 2. Expression of FGFs in retinal SAGE database . . . . 12

Figure 3. Expression of Fgfr1-4 and Fgfrl1 in retinal SAGE database . 14

Figure 4. Real time RT-PCR analysis of Fgf15, Fgfr1 and Fgfrl1 . . 16

Figure 5. In situ hybridization of Fgfr1, Fgfr2, Fgfr3 and Fgfrl1 in the developing mouse retina $. \quad . \quad . \quad . \quad . \quad . \quad 19$

Figure 6. Ectopic Expression of Fgfr1-4, Fgfrl1 and Fgf15 in COS cells . 21

Figure 7. Real time RT-PCR analysis of Fgf receptors in Fgf receptor deficient mice $\quad . \quad$. $\quad . \quad$. $\quad . \quad$. . . 23

Figure 8. Analysis of the presence of persistent progenitor cell markers in Fgf receptor deficient mice . . . . . 24

Figure 9. Analysis of a decrease in later born cell types in Fgf receptor deficient mice $\quad . \quad$. $\quad . \quad$. $\quad . \quad$. $\quad .26$

Figure 10. Analysis of abnormal OPL with the Fgfr mutant mice. . . 27

Figure 11. Visual acuity appears to be normal in Fgfr KO mice. . . 29

Figure 12. Fgfr KO mice show normal ranges of intraocular pressure . 31

Figure 13. Analysis of the presence of persistent progenitor cell markers in Fgf15 explant cultures . . . . . . 34

Figure 14. Analysis of a decrease in later born cell types in Fgf15 explant cultures . . . . . . . . 35

Figure 15. Analysis of Fgf and Fgf receptor expression in Fgf15 explant cultures $\quad . \quad . \quad . \quad . \quad . \quad . \quad . \quad . \quad 36$

Figure A-1. Real time RT-PCR analysis of Fgf10, Fgf12 and Fgf13 . . 45

Figure A-2. In situ hybridization of NF68 and Cyclin D1 in the developing mouse retina 


\section{LIST OF ABBREVIATIONS}

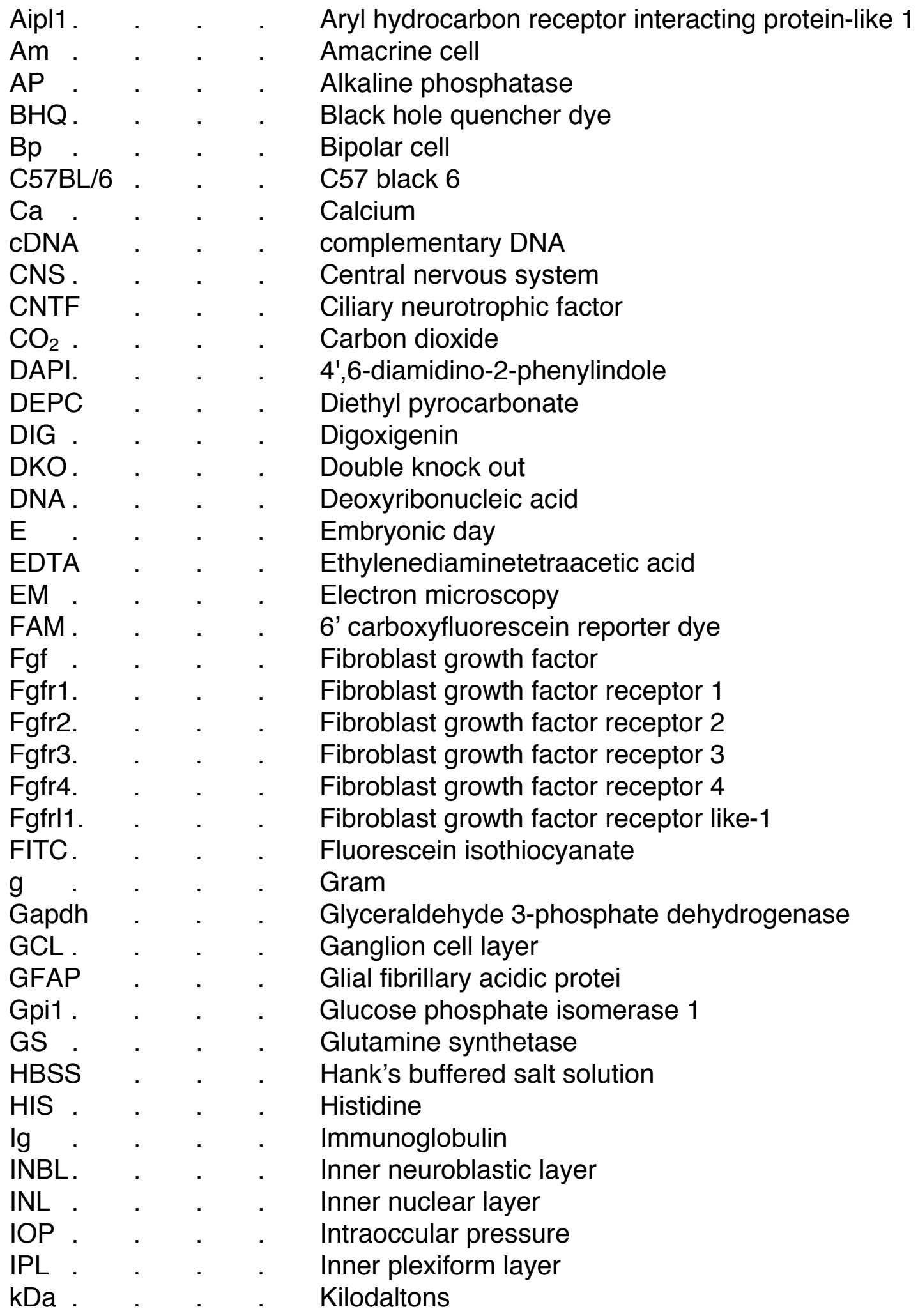




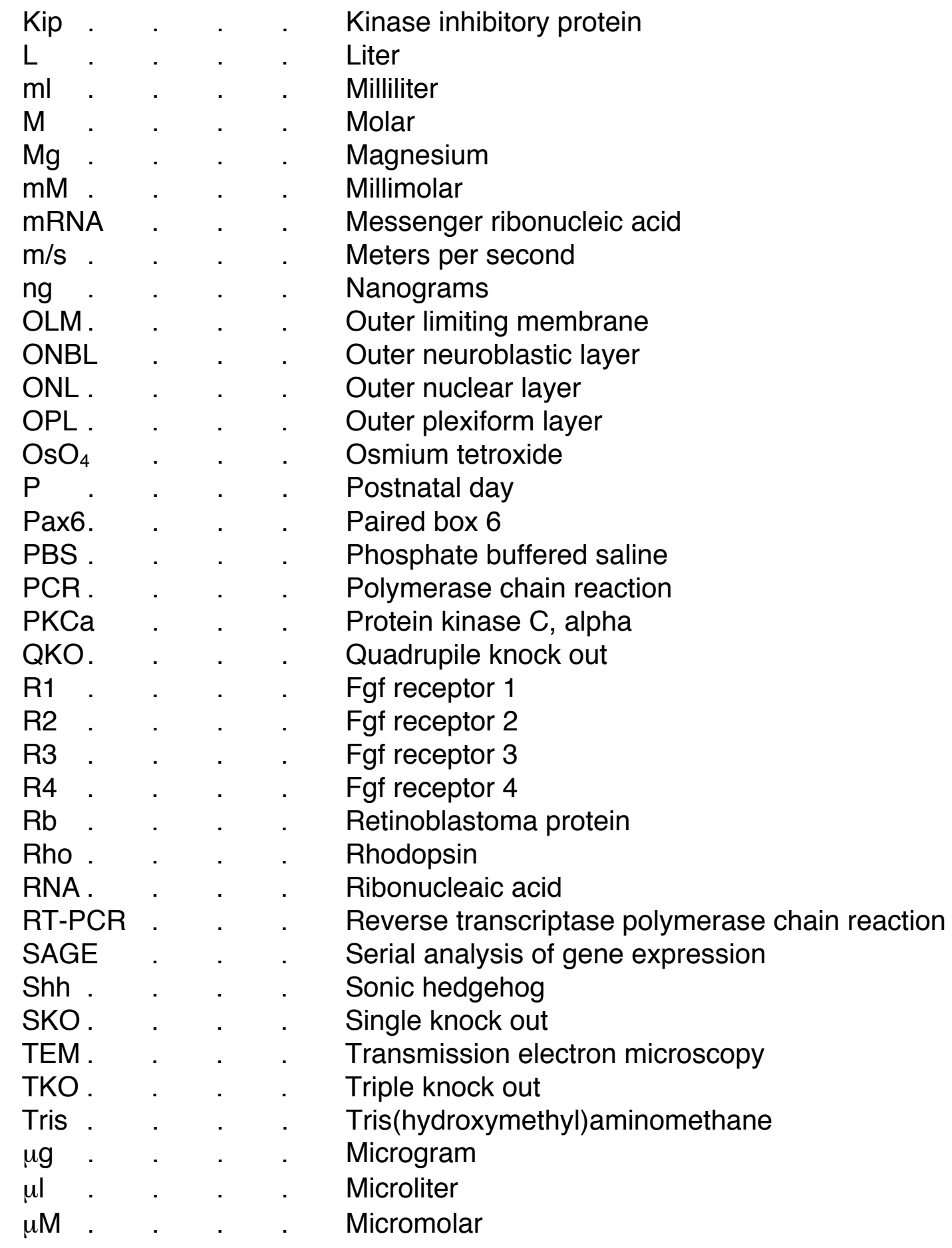




\section{CHAPTER I. BACKGROUND AND SIGNIFICANCE}

\section{Anatomy of the retina}

In the vertebrate central nervous system (CNS) the retina has been a useful model for studying neurogenesis (Livesey and Cepko, 2001). The retina is a thin sheet of neuroepithelium that lines the back of the eye and it is made up of 3 cellular layers separated by 2 plexiform layers (Figure 1A). It is made up of 55-60 different neuronal subtypes that can be grouped into 7 major classes (ganglion cells, rod and cone photoreceptor cells, amacrine cells, bipolar cells, horizontal cells and Müller glial cells)(Jeon et al., 1998).

Each cell type has a distinct role in relaying visual information to the brain for processing. The role of rod and cone photoreceptors is to convert photons of light into chemical and electrical signals that are then transmitted through bipolar neurons within the inner nuclear layer (INL) to the ganglion cells and on to the brain (Wassle, 2004). In general, cones are used for color vision during the day and rods are used for visual perception in low light. Horizontal cells, which reside at the apical side of the INL, moderate the signal from the photoreceptor cells to the bipolar cells through their synaptic connections at the OPL (Sernagor E., 2006). Amacrine cells, found on the basal side of the INL, mediate visual signal procession in the retina before the information is sent to the brain (Purves, 2004). Amacrine cells are the connection between the rod photoreceptors and the ganglion cells (Masland, 2001). Amacrine and bipolar cells make synaptic connections with dendritic processes of ganglion cells within the inner plexiform layer. The radial glia of the retinae are called Müller glia. Their apical microvilli contact the retinal pigment epithelium to form the outer limiting membrane (OLM); and their endfeet form the inner limiting membrane adjacent to the vitreous of the eye. They provide Muller glia important structural and support function, including clearence of secreted neurotranmitters. In addition, in virtually every form of retinal disease or injury, the Müller glia undergo a process of reactive gliosis characterized by changes in their cytoskelaton and secretion of factors important for restoring retinal homeostasis (Dyer \& Cepko, 2000).

\section{Retinal development}

The 7 different classes of retinal cell types are generated from multipotent retinal progenitor cells in an evolutionarily conserved birthorder during development (Figure 1B). Birth-dating studies in the mouse have shown that retinal ganglion cells are one of the first cell types to be generated, while bipolar cells are among the last cell types to be generated (Young, 1985). It has been proposed that intrinsic changes in retinal progenitor cell competence is an 
Figure 1. Development of the mammalian retina. (A) The retina is made up of 7 major classes of cell types (ganglion cells, rod and cone photoreceptor cells, amacrine cells, bipolar cells, horizontal cells and Müller glial cells) organized into three cellular layers. The ONL contains rods and cones. The INL contains bipolar, horizontal, and amacrine cells as well as müller glia. The GCL contains displaced amacrine cells. The cellular layers are separated by two plexiform layers, the OPL and the IPL. (B) Retinal progenitor cells are multipotent and a single progenitor cell can provide all of the cell types in the retina. In addition, the different classes of retinal cell types are produced in an evolutionarily conserved birthorder. In order to explain how a multipotient progenitor cell can produce the different cell types in a precise birthorder, it has been proposed that retinal progenitor cells can undergo unidirectional changes in competence during development. Early stage progenitors are only competent to make early born cell types (e.g. ganglion cells) and late stage progenitors are only competent to make late stage cell types (e.g. bipolar neurons). Abbreviations: ONL, outer nuclear layer; INL, inner nuclear layer; GCL, ganglion cell layer; OPL, outer plexiform layer; IPL, inner plexiform layer. 
A

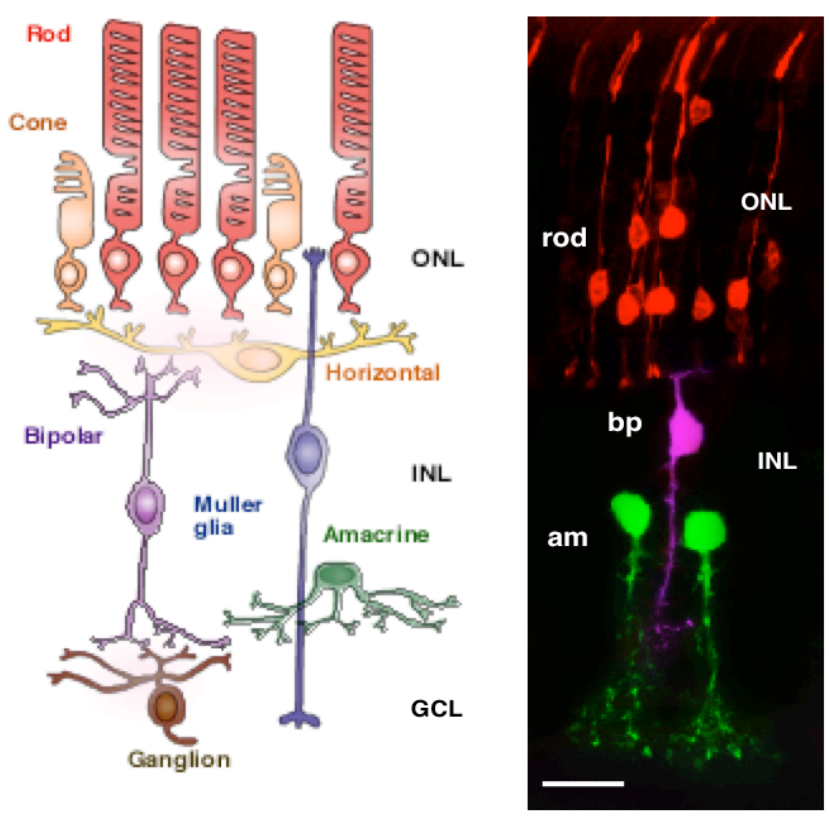

B

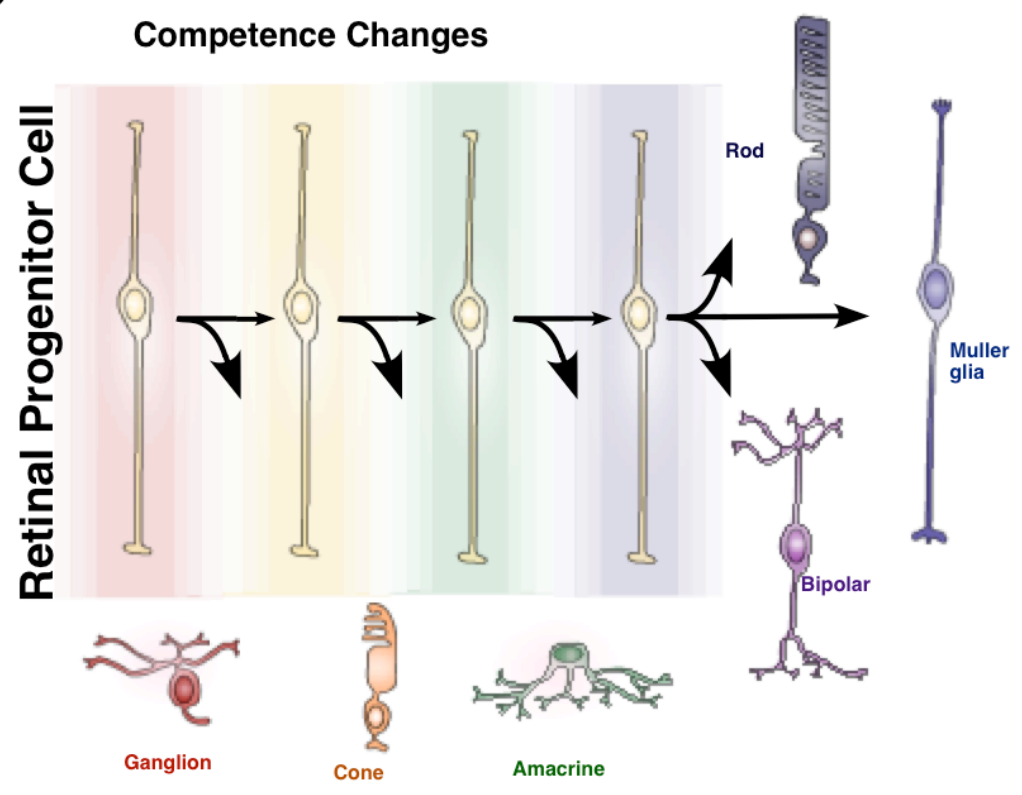


important mechanism to produce each cell type at the proper time during development (Cepko et al., 1996). However, it is also well established that extrinsic cues can influence retinal development. For example, ciliary neurotrophic factor (CNTF) can induce rods to become bipolar cells during retinal development (Ezzeddine et al., 1997). It is the precisely coordinated interplay between intrinsic competence and extrinsic factors that regulates the generation of cell types in the developing retina and similar mechanisms have been found in other regions of the CNS.

The decision to exit the cell cycle must be coordinated with changing cell competence in the developing retina in order to generate the precise ratios of different cell types. If too many cells exited the cell cycle during the early stages of retinal development there would be an increase in early born cell types, such as ganglion cells, at the expense of late born cell types such as bipolar cells. As with retinal progenitor cell competence, it is likely that retinal progenitor cell proliferation is also regulated by a combination of intrinsic and extrinsic factors. For example, cyclin D1, p2 $7^{\text {Kip1 }}, \mathrm{p} 19^{\text {Ink4d }}$ and the Rb family of proteins represent intrinsic regulators of retinal progenitor cell proliferation. Similarly, Shh is an example of an extrinsic factor that may play a role in regulating retinal progenitor cell proliferation during development (Dakubo et al., 2003). Very early during retinogenesis, Shh is secreted by the ganglion cells, which can then influence retinal progenitor cell proliferation and subsequent developmental events such as neuronal differentiation and retinal lamination (Dakubo et al., 2003).

\section{Fibroblast growth factors}

I am interested in the role of Fibroblast growth factors (FGF) signaling during retinal development. In the developing retina, FGFs are a large family of secreted polypeptide growth factors that range in molecular weight from 17 to 34 kDa (Ornitz \& Itoh, 2001; Powers et al., 2000). The majority of FGFs have aminoterminal signal peptides that mediate their secretion into the extracellular milieu. FGFs also have a high affinity for heparan sulfate proteoglycans and require heparan sulfate to trigger the FGF receptors.

Fgf15 is the major Fgf expressed during retinal development in mice. Fgf15 is one of 23 members of the mammalian fibroblast growth factor (Fgf) family, and is an example of an FGF that has been shown to control proliferation, cell fate specification, differentiation and migration during development (Ornitz \& Itoh, 2001; Powers et al., 2000). Fgf15 is believed to be important primarily during development and is not expressed in mature tissues(Blackshaw et al., 2004). Previously published work has shown that $\mathrm{Fgf} 15^{-/-}$mice die embryonic lethally with defects in the development of the cardiac outflow tract (Vincentz et al., 2005; Wright et al., 2004). 
The activity of Fgfs are mediated by four distinct high affinity cell-surface tyrosine kinase receptors (Fgfr1-4)(Ornitz \& Itoh, 2001). As with other tyrosine kinase receptors, ligand binding induces receptor clustering and autophosphorylation followed by recruitment of intracellular substrates to activate gene expression. Each of these receptors consists of an extracellular ligand binding region with two or three lg-like loops, and an intracellular tyrosine kinase domain split by a short kinase insert (Plotnikov et al., 1999). In the absence of ligand, receptors are free to move laterally in the plane of the plasma membrane. In the presence of ligand, two receptors are brought together to form a dimer which is responsible for tyrosine auto-phosphorylation and phosphorylation of target substrates (Ornitz, 2000; Powers et al., 2000). Recently, an FGF receptor called fibroblast growth factor receptor like-1 (Fgfrl1) was identified and characterized (Wiedemann \& Trueb, 2000). Fgfrl1 has an extracellular domain similar to the other FGFRs, but it is lacking the intracellular tyrosine kinase domain. Fgfrl1 can bind FGFs but it cannot signal downstream targets (Wiedemann \& Trueb, 2000).

In general, FGFs are believed to be somewhat promiscuous for binding to different Fgf receptors. It is not known if Fgf15 binds preferentially to individual Fgfrs in the developing retina. Knockout mice for each of the receptors have been created and used for a variety of developmental studies. Fgfr $1^{-1-}$ mice die prior to gastrulation due the defects in the primitive streak formation (Deng et al., 1997; Deng et al., 1994; Trokovic et al., 2003; Yamaguchi et al., 1994). For this reason a conditional knockout was created to study the effects Fgfr1 inactivation at later stages of development. Fgfr ${ }^{\text {Lox/Lox }}$ mice are indistinguishable from their wild-type littermates (Pirvola et al., 2002; Xu et al., 2002).

$\mathrm{Fgfr}^{-/-}$mice are embryonic lethal at day 4 of development, due to failure of implantation (Arman et al., 1998; Weinstein et al., 1998). The conditional knockout was created and Fgfr2 ${ }^{\text {Lox/Lox }}$ mice are phenotypically wild type (Yu et al., 2003). Fgfr $^{-/-}$mice are viable and fertile. These mice suffer skeletal dysphasia (bowlegged) due to increased growth of long bones. $\mathrm{Fgfr}^{-/-}$mice also exhibit kyphosis (curvature of the spine) and a wavy or long tail. Furthermore, they have developmental problems associated with hearing, lungs as well as behavioral deficiencies (Colvin et al., 1996; Deng et al., 1996). Fgfr4 $4^{-1-}$ mice develop normally and live past one year of age. The mice often weighed $10 \%$ less than their littermates at weaning, but can successfully reproduce (Weinstein et al., 1998). A systematic characterization of retinal development has not been carried out on Fgfr-deficient mice.

Several different Fgfr compound knockout mice have been generated and analyzed for developmental defects. $\mathrm{Fgfr}^{-/-} ; \mathrm{Fgfr}^{-/-}$mice were previously tested, and found to be much smaller then their sibling controls (50\%). These mice 
appeared sickly and dehydrated, even more so than the $\mathrm{Fgfr}^{-/-}$mice. They were largely infertile, though a few animals were able to produce progeny. Mice displayed respiratory problems due to defects in alveolar formation. Viability of mice was also poor, most mutants died within the first months of life (Weinstein et al., 1998).

In this research proposal, I will use molecular, cellular and genetic approaches to study the role of FGF signaling in retinal development with particular emphasis on Fgf15 signaling through Fgfr1-4. I am particularly interested in separating out the roles for FGF signaling in retinal progenitor cell proliferation from effects on cell fate specification, differentiation, neuronal survival, synaptogeneiss and neuronal migration. The experimental tractrability of the retina makes this an ideal system to begin to explore these fundamental biological questions. My research may help to advance our understanding of the coordination of extrinsic and intrinsic factors in regulating neurogenesis in the retina and may also identify defects in vision associated with perturbations in this process. 


\section{CHAPTER II. MATERIALS AND METHODS}

\section{Mouse strains}

Chx10-Cre mice were obtained from Dr. Connie Cepko (Harvard Medical School). Fgfr $1^{\mathrm{Lox} /+}$, Fgfr2 ${ }^{\mathrm{Lox} /+}$, $\mathrm{Fgfr}^{+/-}$, and $\mathrm{Fgfr}^{-/ /}$mice were obtained from Dr. David Beebe (Washington University St. Louis). Fgf $15^{+/-}$mice were obtained from Dr. Yasuhide Furuta (University of Texas-Huston). All mice were crossed to C57BI/6 mice purchased from Charles River Laboratories (Wilmington, MA). The St. Jude Children's Research Hospital Institutional Animal Care and Use Committee approved all of the animal experiments. , The breeding scheme was to mate $\mathrm{Fgfr}_{1}{ }^{\text {Lox/Lox }} ; \mathrm{Fgfr}{ }^{\text {Lox/Lox }} ; \mathrm{Fgfr}^{+/-}{ }^{\text {; }} \mathrm{Fgfr}^{-/-}$males and females from strains harboring the individual alleles. These animals can be intercrossed to produce the desired Fgfr $1^{\text {Lox/Lox }} ; \mathrm{Fgfr}^{\text {Lox } / \text { Lox }} ; \mathrm{Fgfr}^{-/-} ; \mathrm{Fgfr}^{-/-}$in $25 \%$ of the offspring.

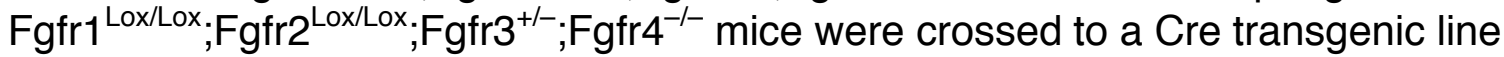
(Chx10-Cre) that expresses Cre recombinase in a mosaic pattern in retinal progenitor cells.

\section{Real time RT-PCR}

Real-time RT-PCR experiments were performed using the ABI $7900 \mathrm{HT}$ Sequence Detection System (Applied Biosystems, Foster City, CA). Primers and probes were designed using Primer Express ${ }^{\circledR}$ software (Applied Biosystems). TaqMan ${ }^{\circledR}$ probes were synthesized with 5'-FAM and 3'-BHQ. RNA was prepared using Trizol, and CDNA was synthesized using the Superscript system (Invitrogen, Carlsbad, CA). Samples were analyzed in duplicate and normalized to Gapdh, Gpi1 expression levels.

\section{In situ hybridization}

For in situ hybridization, retinas from stages E14.5, E17.5, P0, P3, P6, $\mathrm{P} 12$ and adult were rapidly dissected, fixed for 1 hour in 4\% paraformaldehyde, cryoprotected in 30\% sucrose/PBS and embedded in OCT before freezing on dry ice. Cryosections (14- $\mu \mathrm{m}$ thick) were cut, mounted on slides and dried. In situ hybridization was performed using DIG labeled probes (sense and antisense) corresponding to Fgf15(148-804), Fgfr1(343-3913), Fgfr2(621-861), Fgfr3(33383872), Fgfrl1(1968-2331). For the hybridization process, tissue was washed with $1 \mathrm{X}$ PBS DEPC for 10 minutes, washed with $0.2 \mathrm{~N} \mathrm{HCl}$ for 10 minutes, washed with 1X PBS DEPC for 3 minutes, then washed with 1X PBS DEPC for 3 minutes. Next the tissue was incubated in $0.01 \%$ triton in PBS for 3 minutes, $1 X$ PBS DEPC for 3 minutes twice, and treated with Proteinase K Solution for 10 
minutes. $0.2 \%$ glycine wash was used to stop the reaction and slides were allowed to dry. Finally DIG probe (800ng per slide) was added with hybridization solution and the slides were left to incubate at $55^{\circ} \mathrm{C}$ overnight in a humidified chamber. The following day slides were washed separately with $4 \mathrm{X}$ SSC, $2 \mathrm{X}$ SSC and $0.1 \mathrm{XSSC}$ at $55^{\circ} \mathrm{C}$. Slides were then blocked and incubated with the anti-DIG-AP antibody $(1: 500)$ overnight at $4^{\circ} \mathrm{C}$. The following day the slides were washed and developed using NBT/BCIP. Reaction was stopped with stop buffer consisting of Tris Base, and EDTA at pH8.0. Slides were mounted using gelvatol.

\section{Immunofluorescence}

Retinal cryosections, vibratome sections or dissociated cells were fixed in paraformaldehyde (4\% in PBS), washed, and treated with hydrogen peroxide ( $1 \%$ in PBS) before incubation in blocking solution [PBS containing $0.1 \%$ Triton $\mathrm{X}-100$ and $2 \%$ normal serum (Vector Laboratories, Burlingame, CA)]. For each of the antibodies listed below, the dilution used for retinal sections is listed first, followed by the dilution used for dissociated cell staining where applicable. Normal donkey serum was used for the following antibodies: anti-rhodopsin, Rho4D2 [mouse monoclonal, 1:250, 1:2000 (Molday \& MacKenzie, 1983)]; antisyntaxin, HPC-1 (mouse monoclonal, 1:1000, 1:5000; Sigma); anti-calbindinD28K, CL-300 (mouse monoclonal, 1:200, 1:2000; Sigma); anti-FLAG, M2 (mouse monoclonal, 1:100; Sigma); anti-Glutamine Synthetase, G.S. (mouse monoclonal, 1:100; 1:1000; BD Transduction Lab); anti-GFAP, G-A-5 (mouse monoclonal, 1:100,1:2000; Sigma); anti-Pax6 (mouse monoclonal, 1:20, 1:25; DSNB); anti-PKCalpha (mouse monoclonal, 1:100, 1:4000; Upstate). Normal goat serum was used for the anti-cone arrestin (rabbit monoclonal, 1:5000, 1:1000); Anti-Recoverin (rabbit monoclonal, 1:5000; 1:1000; Chemicon). Normal rabbit serum was used for the anti-chx10 (sheep monoclonal, 1:500, 1:1000; Exalpha Bio. Inc). Biotin-conjugated secondary antibodies (donkey anti-mouse IgG, rabbit anti-goat lgG, goat anti-rabbit lgG; Vector Laboratories) were used at a dilution of 1:500 in blocking solution. After secondary antibody binding, an avidin-biotin-peroxidase complex (Vectastain ABC, Vector Laboratories) was incubated with the sections or dissociated cells followed by diaminobenzidine detection (Vector Laboratories), FITC tyramide, or Cy-3 tyramide detection (DuPont NEN, Wilmington, DE) according to the manufacturers' instructions (Bobrow et al., 1991). For some experiments, flurophor-conjugated tyramine compounds and reaction buffers were synthesized according to previous reports (Bobrow et al., 1991) equivalent results. For nuclear staining, DAPI was added to the final wash solution at $0.0005 \%$. 


\section{Microscopy}

Bright-field and single-cell fluorescent images were obtained using a Zeiss Axioplan-2 fluorescent microscope with the Zeiss AxioCam digital camera. Fluorescent images of tissue sections were obtained using a Leica TCSNT confocal microscope.

\section{Retinal dissociations}

Retinae from mice or tissue from cultured explants was analyzed by gentle dissociation. Dissociations were conducted as described by Altshuler and Cepko (1992) with slight modification. Briefly, neural retinae were dissected free of other ocular tissues and incubated for 10 min at room temperature in HBSS lacking $\mathrm{Ca} 2+/ \mathrm{Mg} 2+$ (Life Technologies) to which trypsin (Worthington, Freehold, NJ) was added to a final concentration of $1 \mathrm{mg} / \mathrm{mL}$. After trypsinization, soybean trypsin inhibitor (Sigma, St. Louis, MO) was added to a final concentration of $2 \mathrm{mg} / \mathrm{ml}$. The cells were then gently triturated to a single cell suspension in HBSS containing $100 \mu \mathrm{g} / \mathrm{ml}$ DNase I (Sigma). Cells were then plated on poly-D-lysine (Sigma)-coated, eight-well glass slides (Cel-Line Associates, Newfield, NJ) before fixation.

\section{Retinal explant culture and dissociation}

Retinae were dissected away from the surrounding tissue in prewarmed $\left(37^{\circ} \mathrm{C}\right.$ ) explant culture medium (45\% Dulbecco's Modified Eagle's Medium (Gibco) 45\% F12 Nutrient Mix (Gibco), 10\% Fetal Calf Serum (HyClone), 2 mM Lglutamine (Gibco), Penicillin/ Streptomycin (Gibco) and $5 \mathrm{mg} / \mathrm{ml}$ insulin (Sigma)). Immediately following dissection, retinae were placed on polycarbonate filters (13 $\mathrm{mm}$ diameter, $1.0 \mathrm{~mm}$ pore size; Corning) in explant culture medium at $37^{\circ} \mathrm{C}$ and $5 \% \mathrm{CO}_{2} .20 \mu \mathrm{l}$ of conditioned retinal supernatant was added to the explants every 24 hours. E12.5 mouse retinae were cultured for 12 days following infection at the time of dissection. Tissue dissociation was carried out as described previously (Morrow et al., 1998).

\section{Optomotry}

Cone vision was assessed using optometry as described (Prusky et al., 2004). Optomotry uses 4 computer monitors to create a "virtual reality chamber" for the mouse. Individual mice were placed on a round, elevated platform in the center of the arena where they were allowed to move freely. The animal is then surrounded by a moving pattern and will begin to make reflexive head tracking 
movements in the same direction as the moving visual pattern. The position of the animal's head was tracked continuously with the aid of a computer mouse and a crosshair superimposed on a video image of the arena. The $x-y$ positional coordinates of the crosshair in the video frame dictated the hub of the virtual cylinder, thereby enabling the cylinder wall to be maintained at a constant "distance" from the animal's viewing position and effectively "clamping" the spatial frequency of the stimulus. When the cylinder was rotated $(12 \%)$ and the mouse followed with corresponding horizontal head and neck movements (OKR), it was judged that the animal's visual system could distinguish the grating. No tracking should occur when the pattern is not visible.

\section{Tonomotry}

IOP was measured using the TonoLab rebound tonometer for rodents (Colonial Medical Supply). Mice were anesthetized using isoflourine, and IOP was measured with the rebound tonometer. The method is based on impacting a very light probe to the eye at the very low speed $(11-13 \mathrm{mg}, 0.1-0.2 \mathrm{~m} / \mathrm{s})$ and measuring the motion parameters of the probe during collision to the eye (deceleration, impact time, etc,). All IOP measurements were performed between $7 A M$ and 10 AM(Danias et al., 2003).

\section{Transmission electron microscopy}

For transmission electron microscopy (TEM), animals were anesthetized with avertin until a loss of deep tendon reflexes. Transcardial perfusion was performed with carboxygenated Ames medium supplemented with $40 \mathrm{mM}$ glucose to clear the vasculature, followed by perfusion with Sorenson's phosphate buffer $(\mathrm{pH} 7.2)$ with $2 \%$ EM grade paraformaldehyde and $1 \%$ EM grade glutaraldehyde. Eyes were then harvested, a slit was made in the cornea to aid in diffusion, and the tissue was placed in 3\% glutaraldehyde in Sorenson's phosphate buffer overnight. Tissue was washed with $0.2 \mathrm{M}$ cacodylate buffer in $5 \%$ sucrose, postfixed in $1 \%$ OsO4, embedded, sectioned, and viewed by TEM. 


\section{CHAPTER III. EXPERIMENTAL RESULTS}

\section{Expression of Fgf15 and Fgfr genes in the developing retina}

To begin to characterize the expression of the FGFs and Fgf receptor genes in the developing retina, I queried the retinal SAGE database (Blackshaw et al., 2004). I analyzed only the SAGE tags that were unambiguous for the 22 different FGFs, Fgfr1-4 and Fgfrl1. 6 of the FGF genes were expressed in the developing retina with Fgf15 expressed at the highest levels (Figure 2). Fgfr1-4 and Fgfrl1 were also expressed in the developing retina (Figure 3). The SAGE dataset revealed that Fgfr1 expression within the developing retina was greater than the expression levels of Fgfr2-4 combined. The expression pattern also suggests that the Fgfr1 expression pattern parallels that of Fgf15.

To confirm these SAGE data, I designed real time RT-PCR Taqman probes and primers for Fgf15, Fgf10, Fgf12, Fgf13, Fgfr1-4 and Fgfrl1. I validated each probe/primer set, and generated standard curves using retinal cDNA. Next, I collected retinae from 8 stages of development (E14, E17, P0, P3, P6, P9, P12 and adult) using C57BI/6 mice. RNA was purified using the Trizol reagent and cDNA was synthesized for each sample. Real time RT-PCR was carried out in duplicate using two independent samples for each developmental stage. Data were normalized to Gapdh and Gpi1 (Figure 4A-C and Figure A-1). The overall trend in expression of the FGFs and FGF receptors was similar to that predicted from the SAGE database. However, the magnitude of the change in expression was more pronounced in the real time RT-PCR data. For example, Fgf15 expression decreased by 1000 -fold by real time RT-PCR but only 100 -Fold by SAGE (Compare Figure 4A to $2 \mathrm{~A}$ ).

I also analyzed the expression of the Fgf10, Fgf12, and Fgf13 probes during 8 stages of retinal development (Figure A-1). These probes have a lower expression than that of Fgf15. Moreover, their expression seems to be highest in postnatal stages of development when Fgf15 expression is very low. The overall pattern of expression of each of these genes was similar to that seen from the SAGE dataset (Figure 2).

My real time RT-PCR data and the SAGE analysis suggest that Fgf15 is the major FGF expressed in the developing mouse retina and Fgfr1 is the major FGF receptor expressed in embryonic retinal progenitor cells along with Fgf15. To determine which cells expressed Fgf15 and Fgfr1 in the developing retina, I performed in situ hybridization on retinae from 6 stages of development (E14.5, E17.5, P0, P3, P6 and adult) using DIG labeled antisense probes. The corresponding sense probes were used as controls as well as two well characterized in situ probes (cyclin D1 in retinal progenitor cells and Nf68 in 
Figure 2. Expression of FGFs in retinal SAGE database. (A-F) The retinal SAGE database from Blackshaw and Cepko was analyzed for expression of all 23 FGFs during development. 6 Fgfs are expressed in the developing retina and (A) Fgf15 is expressed at the highest levels. (G) Fgf15 expression undergoes a dramatic drop in expression around P0. Abbreviations: E, Embryonic; P, Postnatal. 

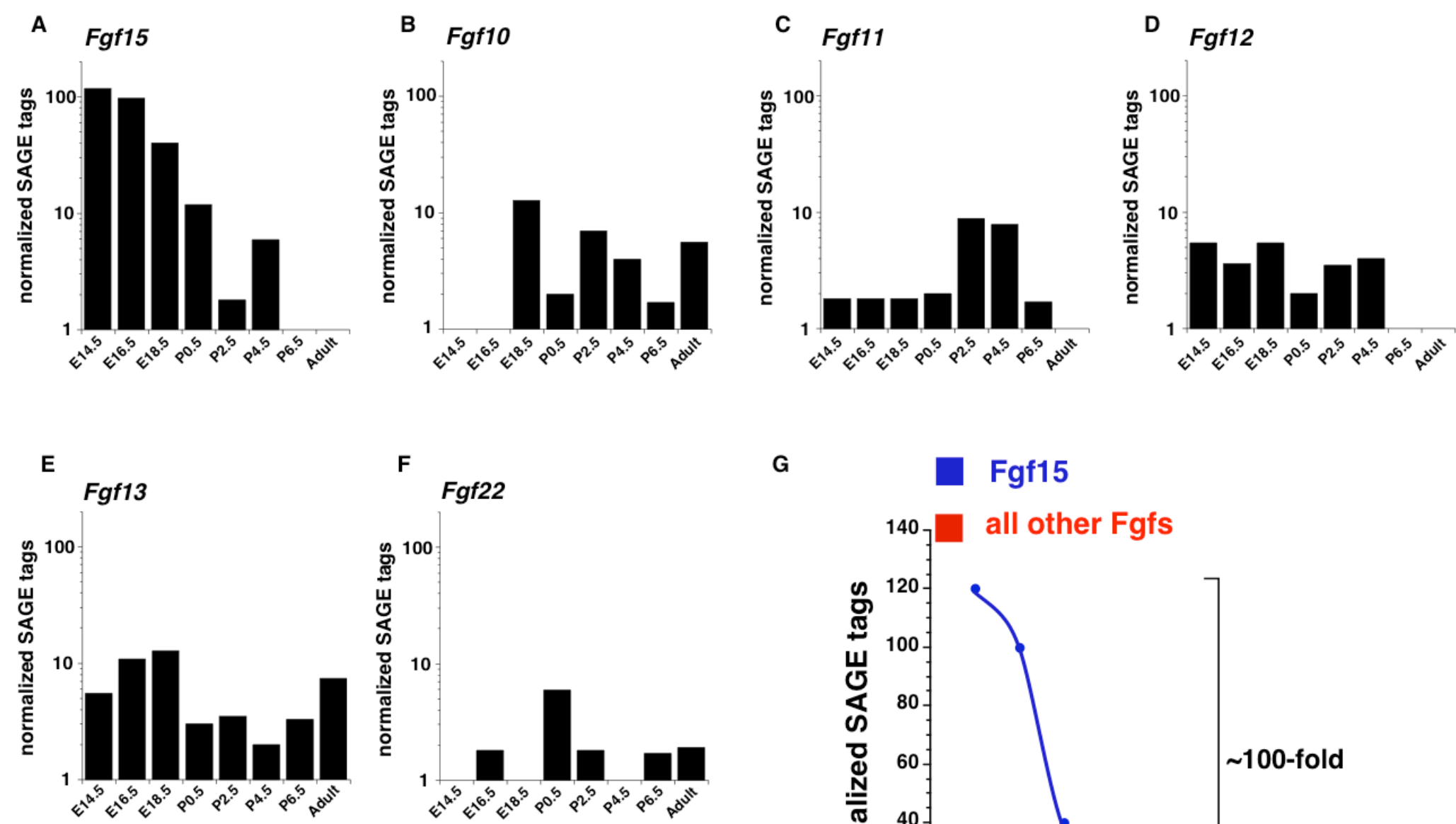

G

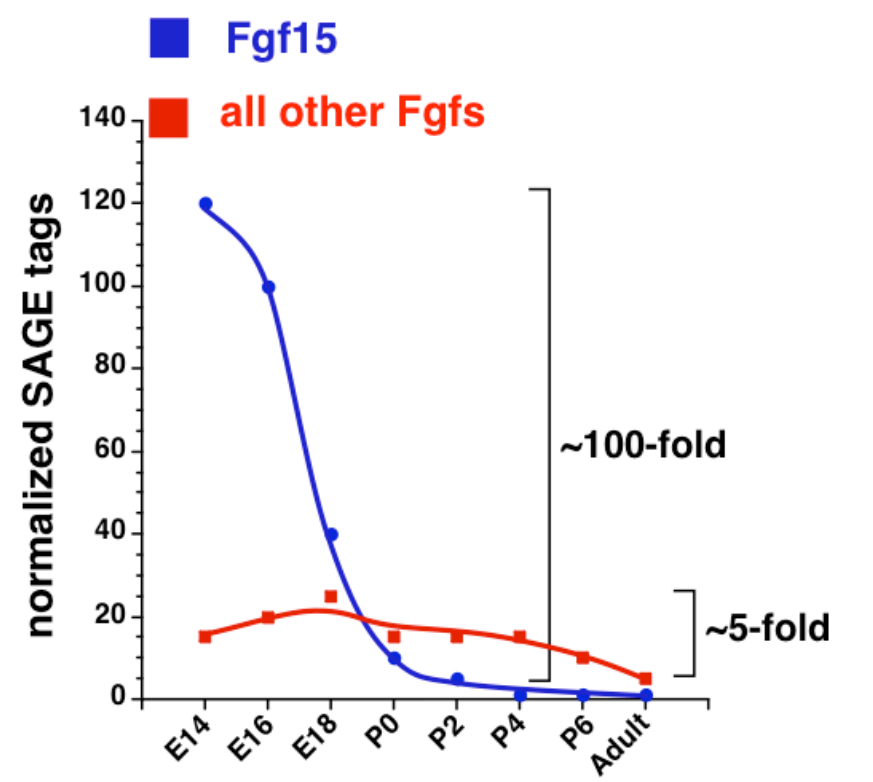


Figure 3. Expression of Fgfr1-4 and Fgfrl1 in retinal SAGE database.

(A) The retinal SAGE database from Blackshaw and Cepko was analyzed for expression of all Fgfr1-4 and Fgfrl1 during development. (B) Fgfr2 was only expressed at very low levels and it at the limit of significance for this assay. (C) Fgfr3 was also expressed at relatively low levels at several stages of mouse retinal development and (D) Fgfr4 was at the lower limit of significance. (E) There was significant expression of Fgfrl1 during mouse retinal development. Reliable tags are those that can be unambiguously assigned to the genes of interest. (F) Fgfr1 was expressed at the highest levels in the developing mouse retina compared to the other Fgfrs. Abbreviations: E, Embryonic; P, Postnatal. 

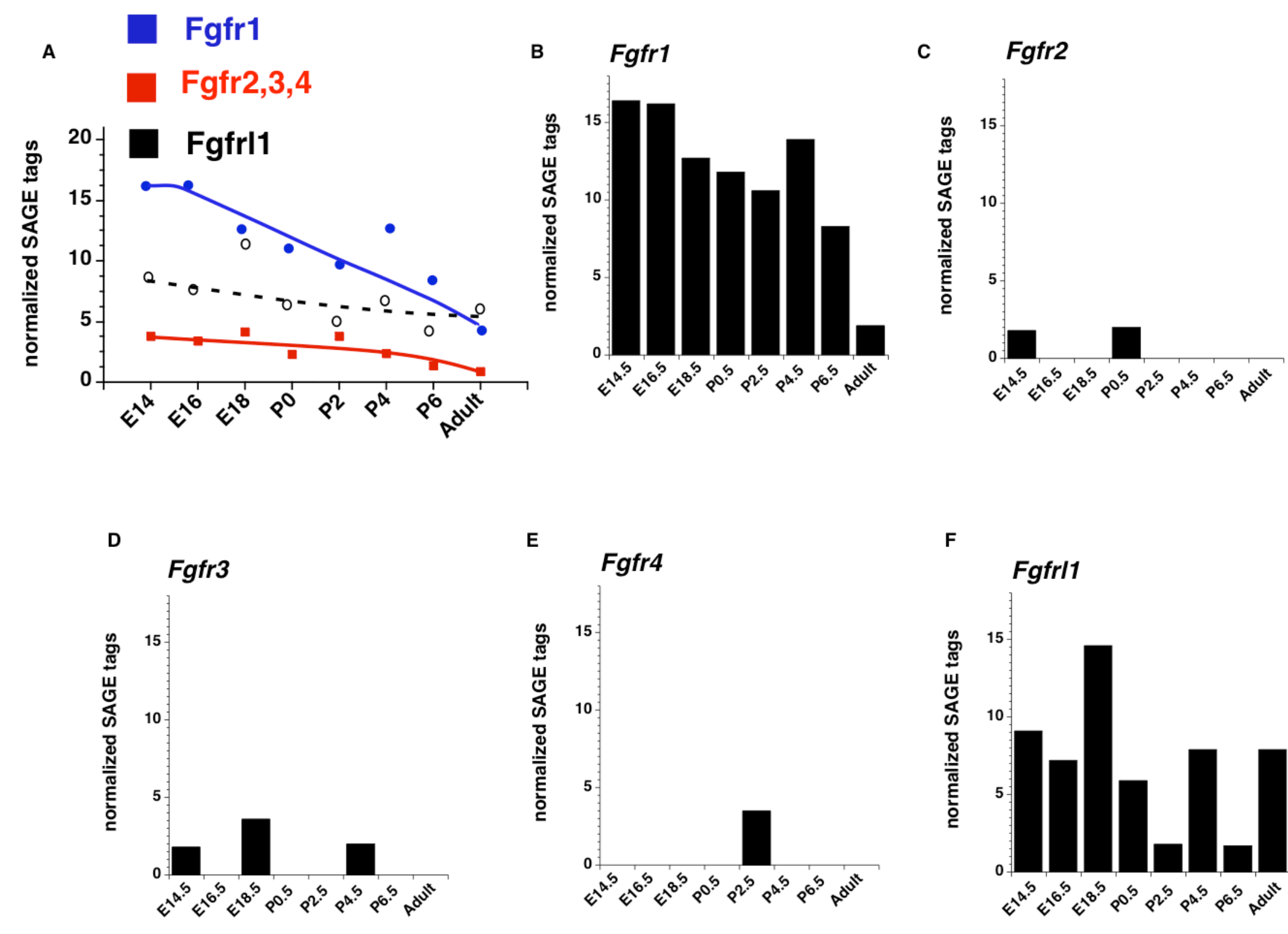

E
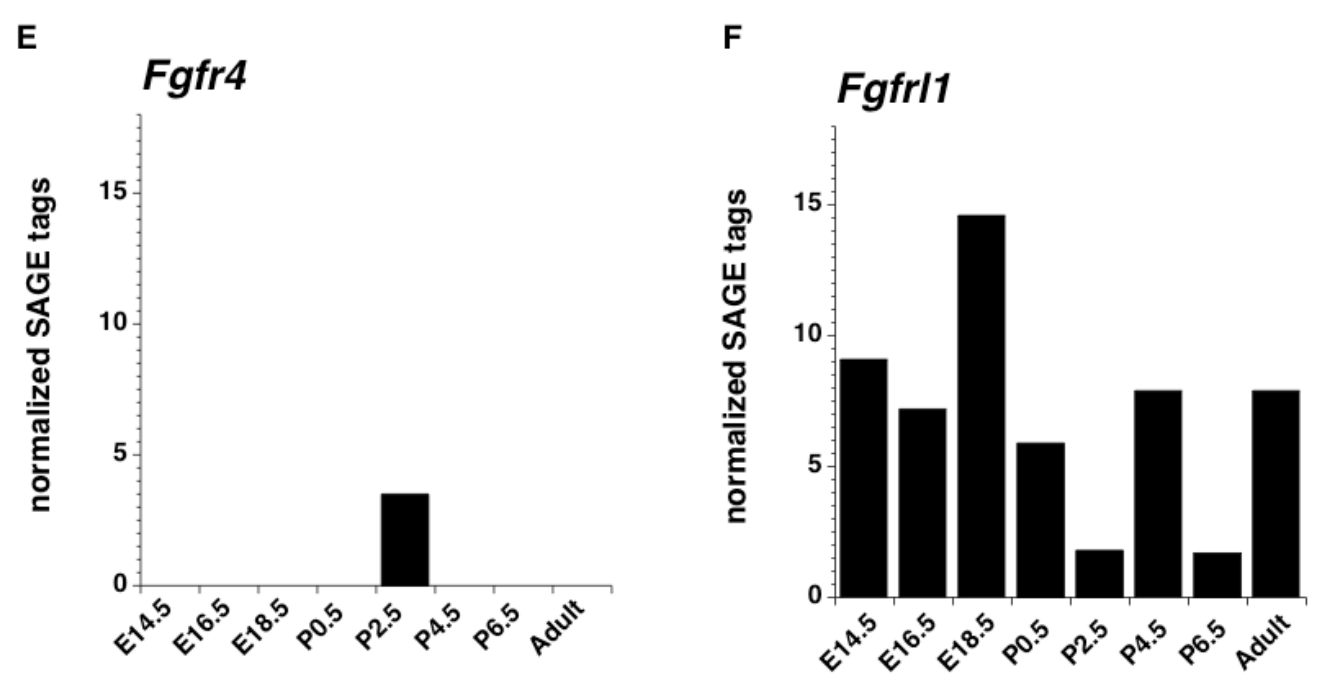
Figure 4. Real time RT-PCR analysis of Fgf15, Fgfr1 and Fgfrl1. Real time RT-PCR was performed for 8 stages of retinal development and data were normalized to internal controls (Gapdh or Gpi1). Relative fold is plotted by setting E14.5 levels to 1.0. (A) Fgf15 expression changes by as much as 1,000 fold during retinal development with the highest levels in the embryonic retina. (B) Fgfr1 was also expressed at the highest levels in the embryonic retina. (C) Fgfrl1 was expressed at the highest levels in the embryonic retina but persists at lower levels in the later stage of development. (D) Sense and antisense probes for Fgf15 were DIG labeled and hybridized to mouse retinal cryosections. At E14.5 and E17.5, Fgf15 was expressed in outer neuroblastic layer (ONBL) where retinal progenitor cells reside. There was no evidence for expression in the newly postmitotic cells of the developing INBL. Abbreviations: E, Embryonic; P, Postnatal; INBL, inner neuroblastic layer; ONBL, outer neuroblastic layer. 

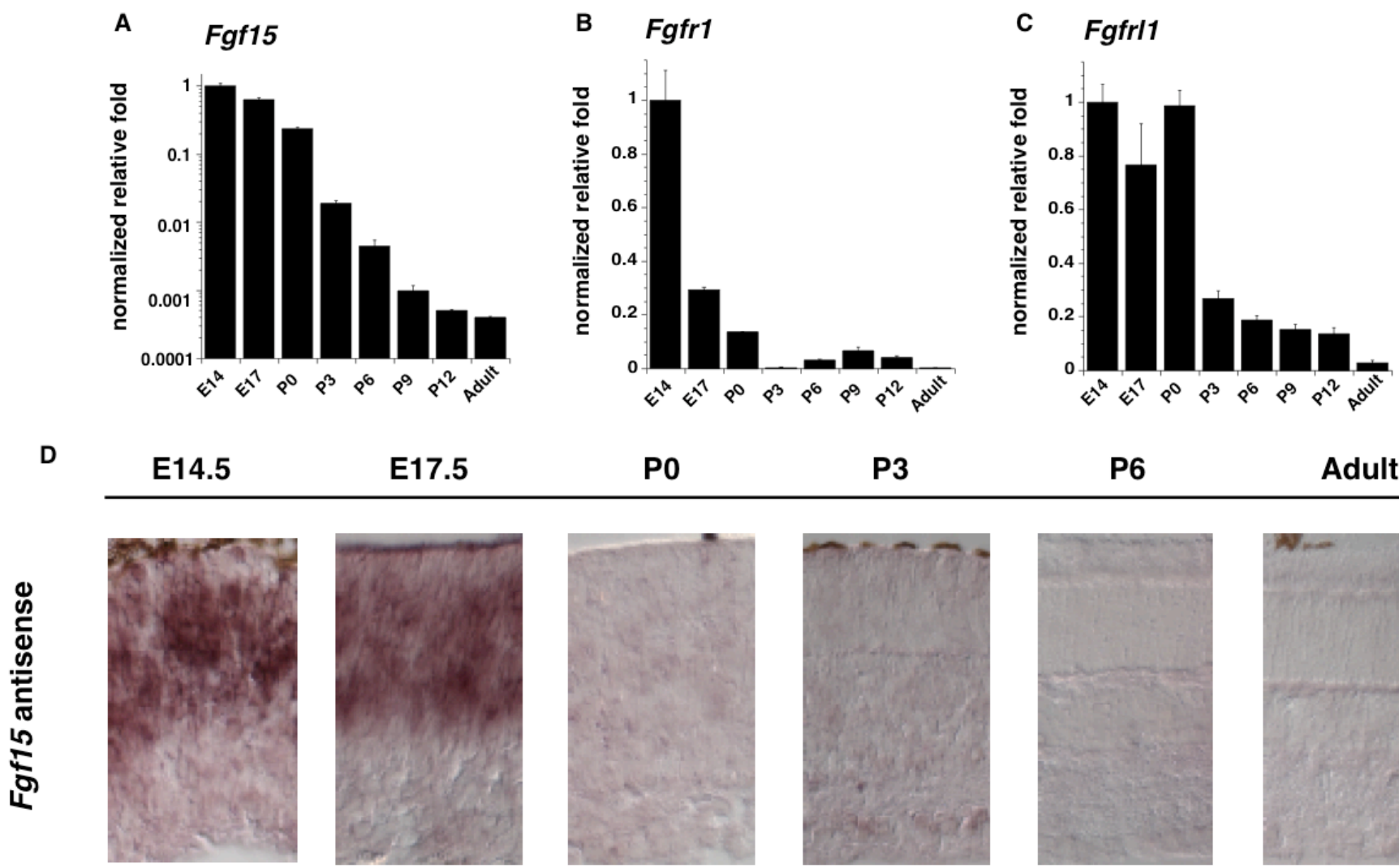

E17.5

PO

P3

P6

Adult
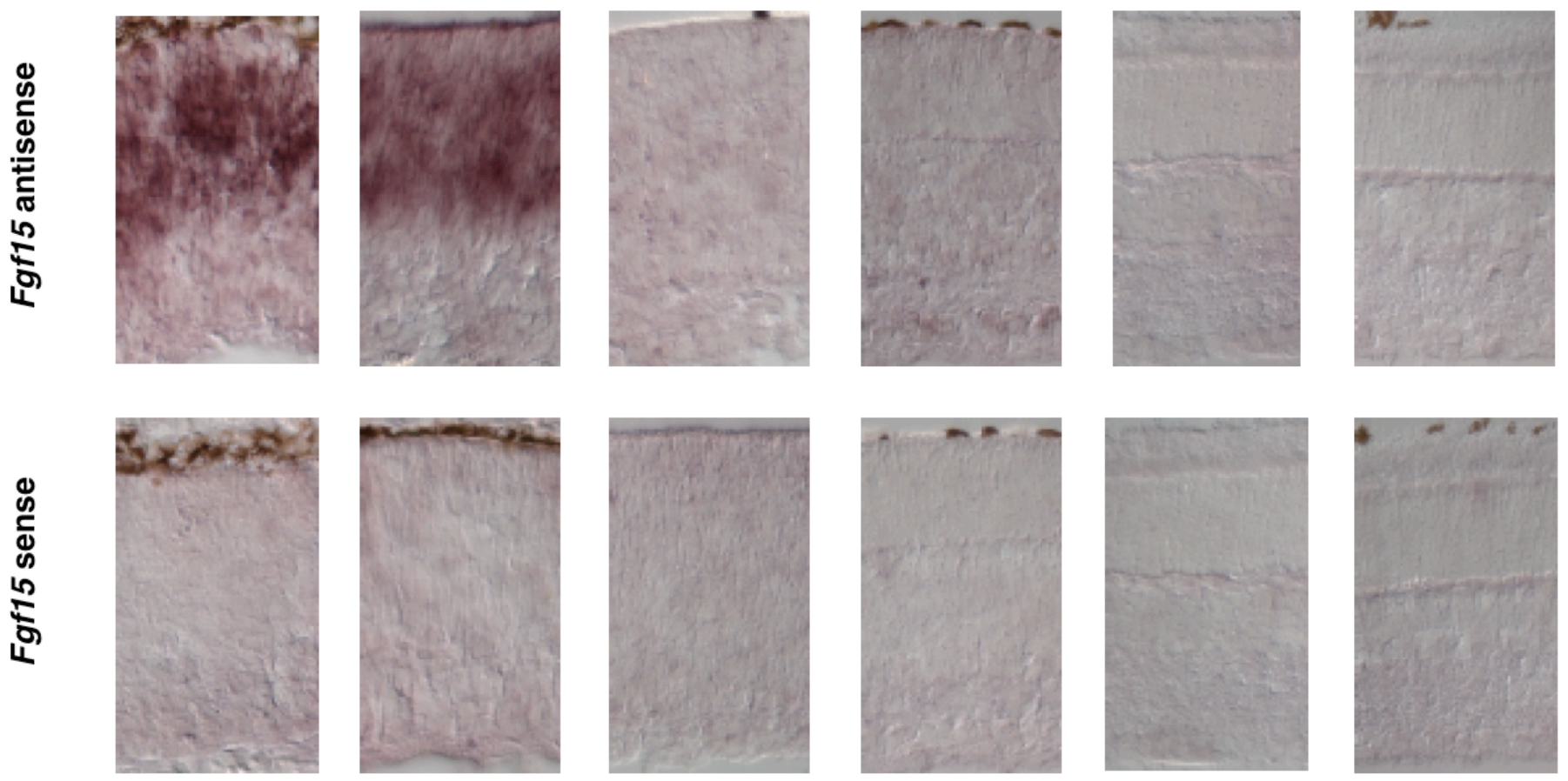
differentiated ganglion cells) that are expressed in a complementary pattern during retinal development (Figure A-2). At E14.5 and E17.5, Fgf15 was expressed in outer neuroblastic layer (ONBL) where retinal progenitor cells reside. By P0 there was very little expression detected. The few progenitor cells that still expressed Fgf15 at P0 were in the periphery of the retina consistent with the central to peripheral gradient of retinogenesis (data not shown). There was little or no expression of Fgf15 in the inner neuroblastic layer (INBL) where newly postmitotic ganglion and amacrine cells are found. There was no expression of Fgf15 at later stages of development. This expression pattern was comparable to that of Cyclin D1, which is expressed in actively proliferating cells (Figure 4D and Figure A-2). My positive control NF68 showed specific hybridization at all stages analyzed confirming the integrity of the mRNA in the tissue used (Figure A-2). The Fgf15 sense control probe hybridized side-by-side with the Fgf15 antisense probe showed no staining at any stage of development (Figure 4D). The data suggest that retinal progenitor cells express high levels of Fgf15 and it is turned off as they exit the cell cycle. Also, my data suggest that postnatal retinal progenitor cells do not express Fgf15.

The Fgfr1 gene was expressed throughout the developing retina in progenitor cells and postmitotic neurons at all stages (Figure 5A). Similar results were obtained for Fgfr2-3 and Fgfrl1 (Figure 5B-D). These data suggest that the specificity of FGF signaling in the developing retina may lie in the temporal and spatial expression of the FGFs rather than the receptors. Of course it is possible that other cell intrinsic factors regulate the cell-type specific response to Fgfr signaling.

\section{Characterization of Fgf15, Fgfr1-4 and Fgfrl1 expression vectors}

One of the advantages of the retina as an experimental system is its tractability. We can readily perform in vivo square wave electroporation using a variety plasmid constructs to ectopically express Fgfs or Fgf receptors. I have not had time to complete these experiments but I have completed the characterization of the expression vectors for future studies. One experiment that I believe would be very interesting to carry out will be to ectopically express Fgf15 and/or Fgfr1 in the postnatal retinal progenitor cells after these genes have been silenced. If Fgf15 signaling is sufficient to drive retinal progenitor cell proliferation we might observe ectopic proliferation when Fgf15 is ectopically expressed.

To ectopically express Fgf15, Fgfr 1-4 and Fgfrl1 the full-length cDNA was subcloned into an expression vector (pUB) that the Dyer lab routinely uses for expressing genes in the developing retina. To determine if the full-length protein was expressed from these expression vectors, I transfected the plasmids 


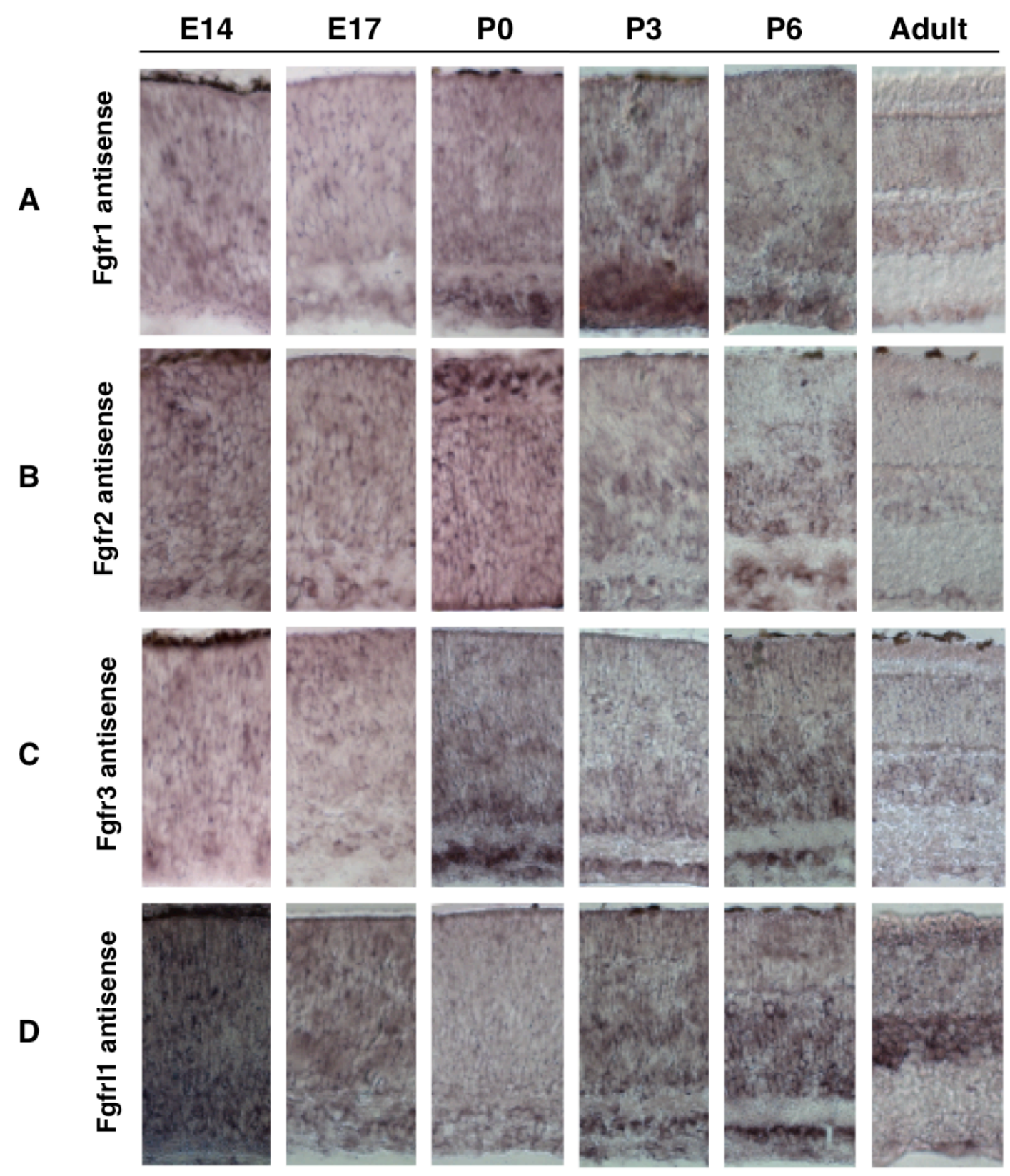

Figure 5. In situ hybridization of Fgfr1, Fgfr2, Fgfr3 and Fgfrl1 in the developing mouse retina. (A-D) Sense and antisense probes for (A) Fgfr1, (B) Fgfr2, (C) Fgfr3 and (D) Fgfrl1 were DIG labeled and hybridized to mouse retinal cryosections for 6 stages of retinal development. Expression of the Fgfr was throughout the retina and not localized to a specific region of the developing retina. Abbreviations: E, Embryonic; P, Postnatal 
separately into COS cells and performed a western blot to probe for the protein expression (Figure 6). The vectors contain a FLAG epitope tag on the amino terminus of protein and a $6 x$ His tag on the carboxy terminus of the protein. For Fgfr1-4 and Fgfrl1 I used the Flag antibody for detection of the clone and used untransfected cells as a negative control. For Fgf15, I used an anti-Flag antibody as well as an anti-HIS antibody for detection of the $25 \mathrm{kDa}$ protein. I was able to detect Fgf15, Fgfr1-4 and Fgfrl1 expression from these plasmids by immunoblotting and these constructs are now ready for in vivo square wave electroporation studies.

\section{Inactivation of Fgfr1-4 in the developing retina}

One approach to begin to elucidate the role of Fgf signaling in the developing retina is to inactivate all 4 of the Fgf receptors. As mentioned above, the Fgfr1 and Fgfr2 knockout mice exhibit an embryonic lethal phenotype (Arman et al., 1998; Deng et al., 1997; Deng et al., 1996; Trokovic et al., 2003; Yamaguchi et al., 1994; Yu et al., 2000). Therefore, I decided to use the Fgfr $1^{\text {Lox }}$ and Fgfr2 ${ }^{\mathrm{Lox}}$ alleles for these studies. Inactivation of Fgfr3 or Fgfr4 alone does not cause a lethal phenotype or severe infertility (Weinstein et al., 1998). However, the $\mathrm{Fgfr}^{-{ }^{--}} ; \mathrm{Fgfr}^{-/-}$mice are infertile. Therefore, in order to generate the desired Fgfr $1^{\text {Lox/Lox }} ; \mathrm{Fgfr}^{\text {Lox/Lox }} ; \mathrm{Fgfr}^{-/-} ; \mathrm{Fgfr}^{-/-}$mice I developed a breeding scheme to produce $\mathrm{Fgfr}{ }^{\mathrm{Lox} / \mathrm{Lox}} ; \mathrm{Fgfr}^{\mathrm{Lox} / \text { Lox }} ; \mathrm{Fgfr}^{+/-}{ } ; \mathrm{Fgfr}{ }^{-/-}$males and females from strains harboring the individual alleles. These animals can be intercrossed to produce the desired Fgfr $1^{\text {Lox/Lox }} ; \mathrm{Fgfr}^{\text {Lox/Lox }} ; \mathrm{Fgfr}^{-/-} ; \mathrm{Fgfr}^{-/-}$in $25 \%$ of the offspring. This strain has been generated and these animals can be used to induce Cremediated recombination of the Fgfr1 and Fgfr2 alleles using retroviruses or in vivo square wave electroporation. I have also crossed the $\mathrm{Fgfr}^{\text {Lox/Lox }} ; \mathrm{Fgfr}^{\text {Lox/Lox }} ; \mathrm{Fgfr}^{+/-}{ }^{\text {; }} \mathrm{Fgfr}^{-/-}$mice to a Cre transgenic line (Chx10-Cre) that expresses Cre recombinase in a mosaic pattern in retinal progenitor cells. I have performed preliminary studies on Chx10-Cre; $\mathrm{Fgfr}{ }^{\text {Lox/Lox }} ; \mathrm{Fgfr}^{\text {Lox/Lox }} ; \mathrm{Fgfr}^{-1-}$ $; \mathrm{Fgfr}^{-/-}$mice in order to begin to understand the role of Fgf signaling in retinal development.

While developing this colony I performed preliminary studies on different combinations of Fgfr knockout mice. The Fgfr single knockouts (SKO) I studied had the genotype $\mathrm{Fgfr}^{-{ }^{--}}$. Double knockout (DKO) mice had the genotype $\mathrm{Fgfr}^{-1-}$ $\mathrm{Fgfr}^{-1-}$. There were two separate variations of the Fgfr triple knockout (TKO) Chx10- Fgfr $1^{\mathrm{Fx} / \mathrm{Fx}} \mathrm{Fgfr}^{\mathrm{Fx} / \mathrm{Fx}} \mathrm{Fgfr}^{-/-} \mathrm{Fgfr}^{+/-} \mathrm{TKO}(\mathrm{R} 1 ; \mathrm{R} 2 ; \mathrm{R} 3)$ and Chx10- $\mathrm{Fgfr}^{\mathrm{Fx} / \mathrm{Fx}}$ $\mathrm{Fgfr}^{\mathrm{Fx} / \mathrm{Fx}} \mathrm{Fgfr}^{+/+} \mathrm{Fgfr}^{-/-} \mathrm{TKO}(\mathrm{R} 1 ; \mathrm{R} 2 ; \mathrm{R} 4)$. Finally the Fgfr quadruple knockout (QKO) mouse retina had the genotype Chx10- Fgfr $1^{\text {Fx/Fx }}$ Fgfr2 $^{\text {Fx/Fx }}$ Fgfr $^{-1-} \mathrm{Fgfr}^{-1 /}$.

For the initial characterization, I analyzed retinae from 2-week old and 3week old mice lacking all 4 Fgfr genes and littermates that had different 

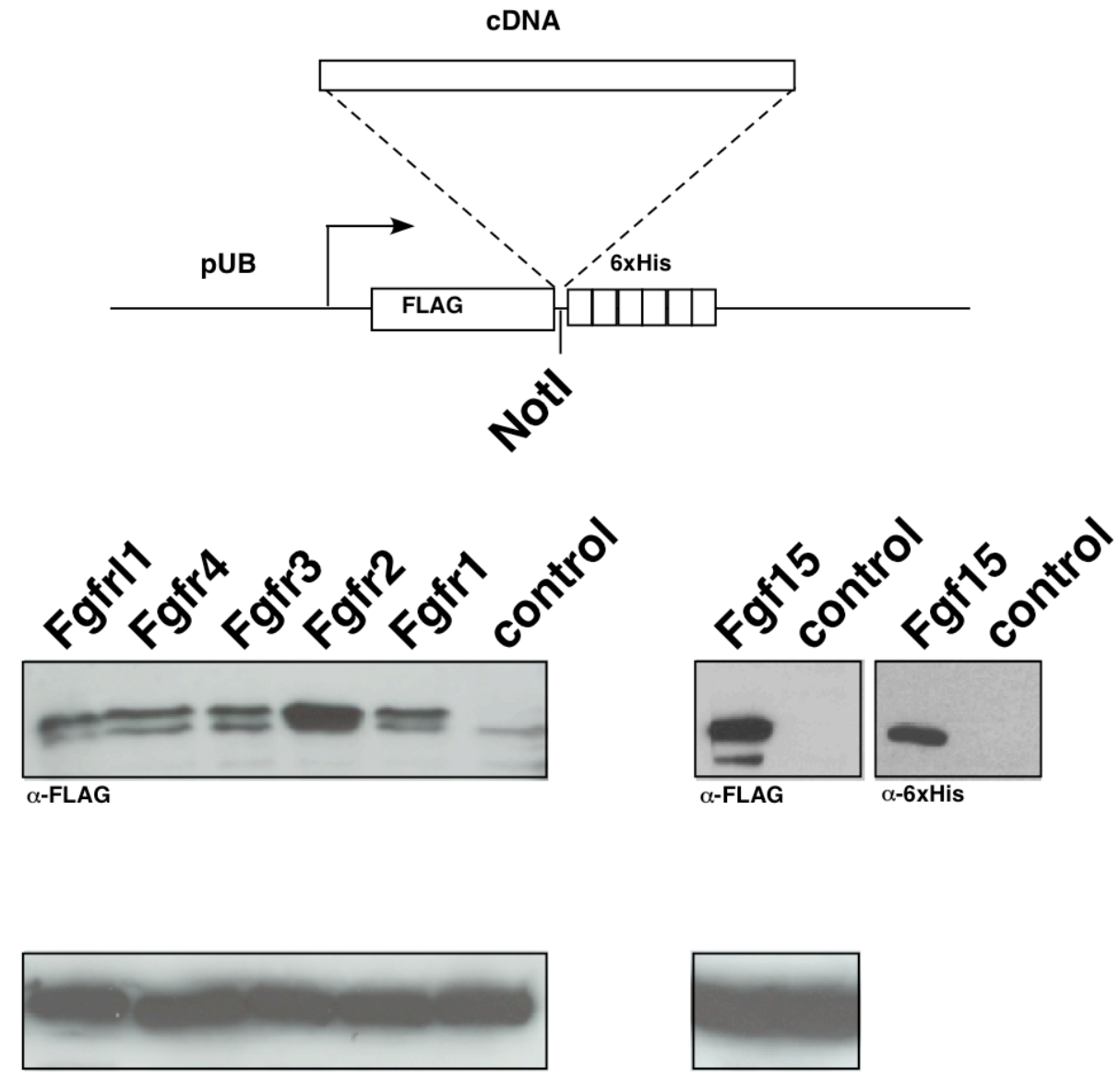

$\alpha$-actin

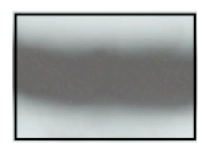

$\alpha$-actin

Figure 6. Ectopic Expression of Fgfr1-4, Fgfrl1 and Fgf15 in COS cells. I subcloned each gene of interest into the pUB expression vector. Each of the cDNAs were cloned in frame to the FLAG epitope and contained a HIS tag. Fgfr1-4 and Fgfrl1 were probed using the anti-Flag antibody, with untransfected COS cells as a negative control. Anti-FLAG and anti-HIS were both used to assay the protein expression of Fgf15, with untransfected COS cells as a negative control. 
combinations of Fgfr genes deleted. A convenient control was mice lacking the Chx10-Cre transgene. I also analyzed wild type retinae side-by-side with my Fgfr knockouts. For each experiment, I performed real time RT-PCR using a variety of cell-type specific Taqman probes and primer sets developed in the Dyer lab. I used probes specific for retinal cell types such as rods (Rhodopsin), cones (Cone Arrestin), Photoreceptors (Recoverin), bipolar cells (PKC $\alpha$ ), Muller Glia (Glutamine Synthetase, GFAP), horizontal and amacrine cells (Calbindin), as well as progenitor cells (Chx10, Pax6, Syntaxin). I also performed dissociated cell immunostaining to score the proportion of each retinal cell type and immunostaining of retinal vibratome sections to study the architecture of the retina. In a parallel study, we examined the cytoarchitecture in greater detail using transmission electron microscopy (TEM).

I performed real time RT-PCR using Taqman probes for retinae from Fgfr 1-4 conditional knockout mice at 2 weeks and 3 weeks of age. 6 independent QKO retinae were analyzed and all real time RT-PCR was performed in duplicate. Using real time RT-PCR, I also observed a 3-4 fold increase in the mRNA expression of Fgfr4, suggesting auto regulation (Figure $7 \mathrm{~A}$ ). $\mathrm{Fgfr}^{-/-}$mice are still able to have transcription of Fgfr4 mRNA because disruption of Fgfr4 was done by interrupting exon 6 , which encodes the Igll domain, with the PGKneo gene. The probe I generated for real time RT-PCR is not in the coding region, but the 3-UTR which was not deleted in this mouse. In contrast there did not appear to be any changes in expression of other Fgf receptors in the Fgf receptor mutant mice (Figure 7B-C). I also found that there was an increase in mRNA expression of progenitor cell markers Chx10 and Pax6 (Figure 8A). This observation was also confirmed through dissociated cell scoring, where persistent expression of Chx10 and Pax6 expression was also observed in the retina of 3 and 4 week old mice (Figure $8 \mathrm{~B}-\mathrm{C}$ ). Immunostaining of the vibratome sections revealed disruptions of the OPL (Figure 8D-E).

I also noticed a decrease in mRNA expression via real time RT-PCR for retinal cell markers of later born cell types for rod photoreceptors (Rho) and bipolar cells $(\mathrm{PKC} \alpha)$ (Figure 9A). Dissociated cell scoring confirmed this observation validating the decrease in PKC $\alpha$ expression (Figure 9B). This finding was consistent for both 3 and 4 week old animals. Immunostaining of vibratome sections further revealed a disruption of the OPL (data not shown).

To study the cytoarchitecture in greater detail I used transmission electron microscopy (TEM). We observed four QKO(R1,R2,R3,R4), one TKO(R1,R2, R4), one DKO (R3, R4) two SKO(R4), and four wild type retina via TEM. Through this method we made the observation of gaps in the photoreceptor layer in the QKO retina and multiple occurances of displaced photoreceptors within the Outer Plexiform layer (Figure 10A-B). Furthermore, the presence of an uneven OPL 
A

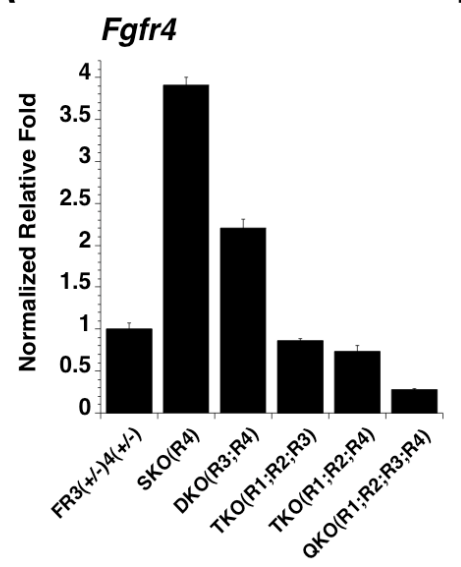

B

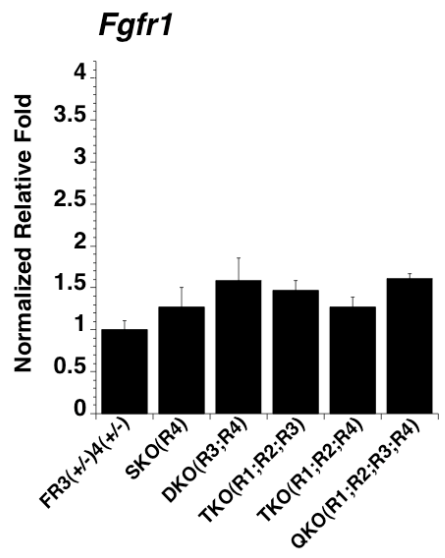

C

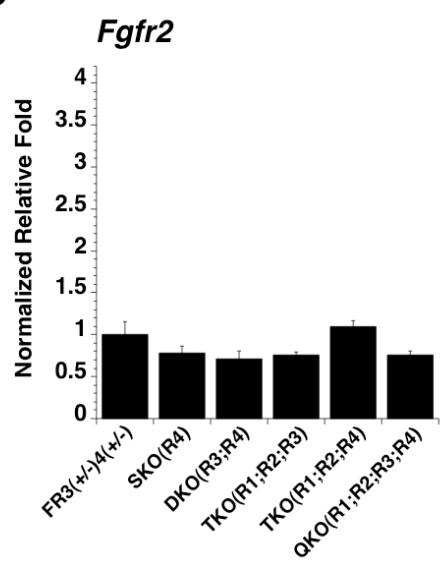

Figure 7. Real time RT-PCR analysis of Fgf receptors in Fgf receptor deficient mice. Real time RT-PCR detected a 3-4 fold increase in the mRNA expression of Fgfr4 (A) in Fgfr deficient mice. There did not appear to be a significant change in the mRNA expression levels of Fgfr1, and Fgfr2 in Fgf receptor deficient mice (B-C). Abbreviations: $\mathrm{SKO}(\mathrm{R} 4)$, single knockout $\mathrm{Fgfr}^{-/ 2}$; DKO(R3;R4), double knockout $\mathrm{Fgfr}^{-/} ; \mathrm{Fgfr}^{-/-}$; TKO(R1;R2;R3), triple knockout Chx10-Fgfr ${ }^{\text {Lox/Lox }} ; \mathrm{Fgfr}^{\text {Lox/Lox }} ; \mathrm{Fgfr}^{-/-} ; \mathrm{Fgfr}^{+/-} ; \mathrm{TKO}(\mathrm{R} 1 ; \mathrm{R} 2 ; \mathrm{R} 4)$, triple knockout Chx10- Fgfr $1^{\text {Lox/Lox }} ; \mathrm{Fgfr}^{\text {Lox/Lox }} ; \mathrm{Fgfr}^{+/+} ; \mathrm{Fgfr}^{-/-} ; \mathrm{QKO}(\mathrm{R} 1 ; \mathrm{R} 2 ; \mathrm{R} 3 ; \mathrm{R} 4)$, quadruple knockout Chx10- Fgfr1 ${ }^{\text {Lox/Lox }} ; \mathrm{Fgfr}^{\text {Lox/Lox }^{2}} \mathrm{Fgfr}^{-/ /} ; \mathrm{Fgfr}^{-/-}$. 
Figure 8. Analysis of the presence of persistent progenitor cell markers in Fgf receptor deficient mice. (A) Real time RT-PCR for mice at stage P21 demonstrated an increase in expression of progenitor cell markers Chx10 and Pax6. (B-C) Dissociated cell scoring revealed a similar decrease in progenitor expression. Immunostaining of (D) Chx10 as well as (E) Pax6 revealed disruptions in the ONL and INL of the mutant retina (arrows). Abbreviations: $P$, Postnatal; ONL, outer nuclear layer; INL, inner nuclear layer; GCL, ganglion cell layer; $\mathrm{SKO}(\mathrm{R} 4)$, single knockout $\mathrm{Fgfr}^{-/-}$; DKO(R3;R4), double knockout $\mathrm{Fgfr}^{-/-}$ ;Fgfr $4^{-/} ; \mathrm{TKO}(\mathrm{R} 1 ; \mathrm{R} 2 ; \mathrm{R} 3)$, triple knockout Chx10-Fgfr1 ${ }^{\text {Lox/Lox }} ; \mathrm{Fgfr}^{\text {Lox/Lox }} ; \mathrm{Fgfr}^{-/-}$ ;Fgfr4 ${ }^{+-}$; TKO(R1;R2;R4), triple knockout Chx10-

$\mathrm{Fgfr}^{\text {Lox/Lox }} ; \mathrm{Fgfr}^{\text {Lox }}{ }^{\text {Lox }} ; \mathrm{Fgfr}^{+/+} ; \mathrm{Fgfr}^{-/ /} ;$QKO(R1;R2;R3;R4), quadruple knockout Chx10- Fgfr $1^{\text {Lox/Lox }} ; \mathrm{Fgfr}^{\text {Lox }^{2} \text { Lox }} ; \mathrm{Fgfr}^{-/ /} ; \mathrm{Fgfr}^{-/-}{ }^{-}$. 


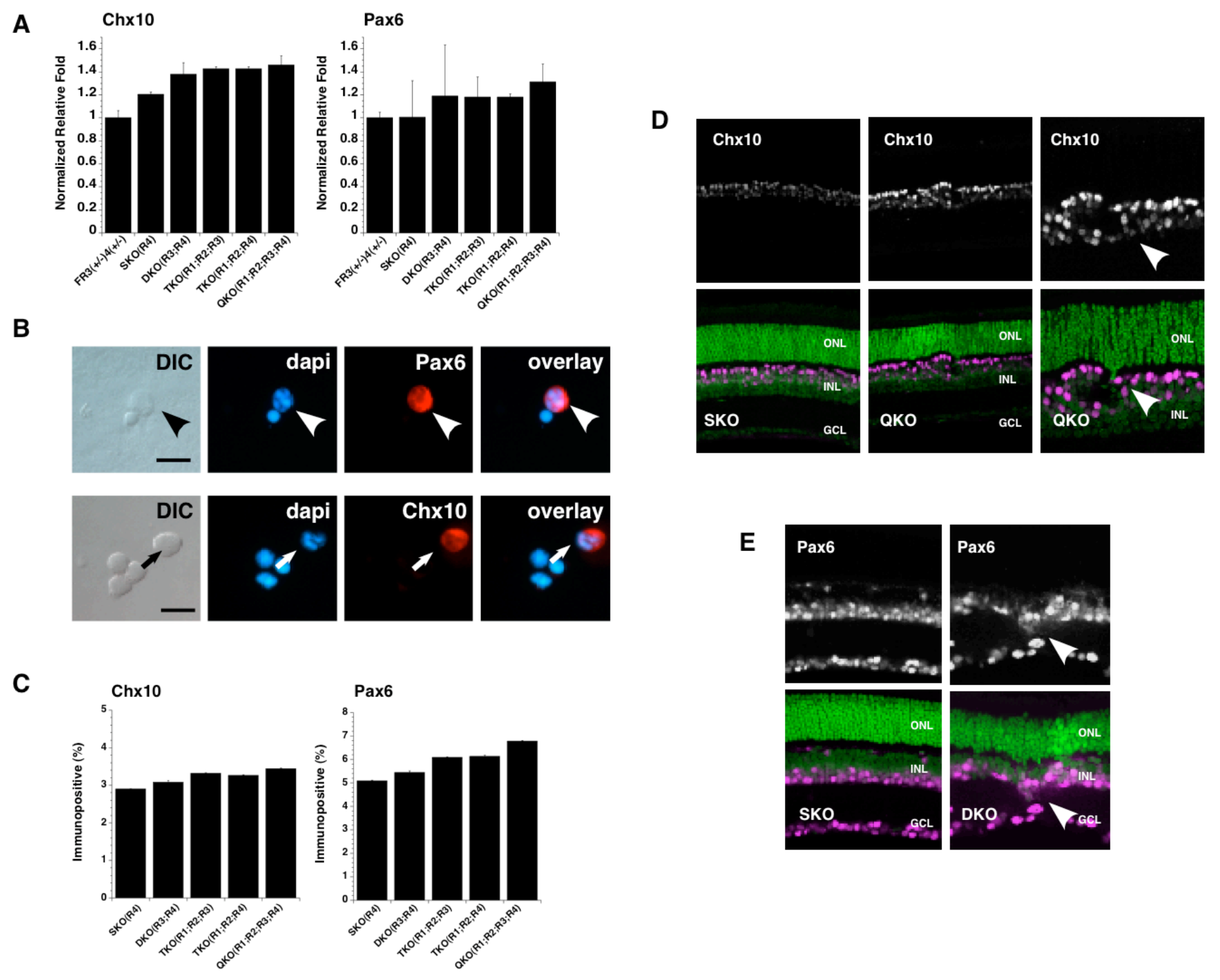


A

PKCa

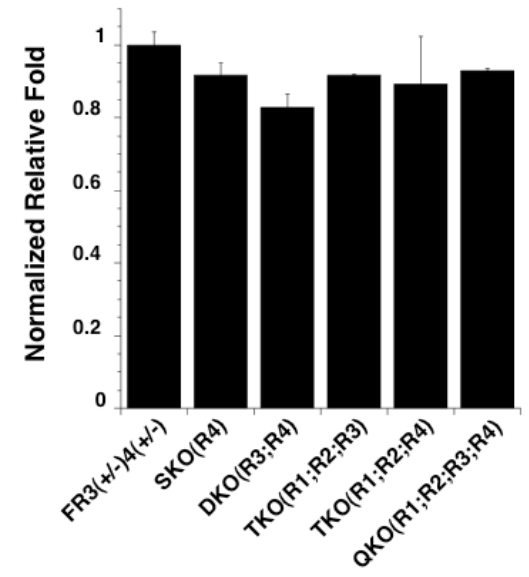

B

PKCa

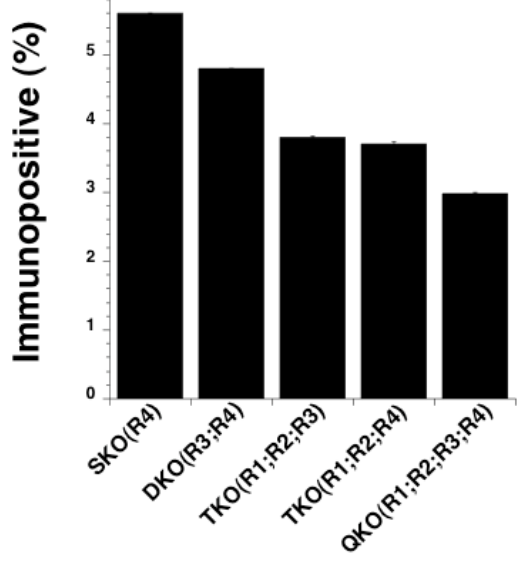

Rho

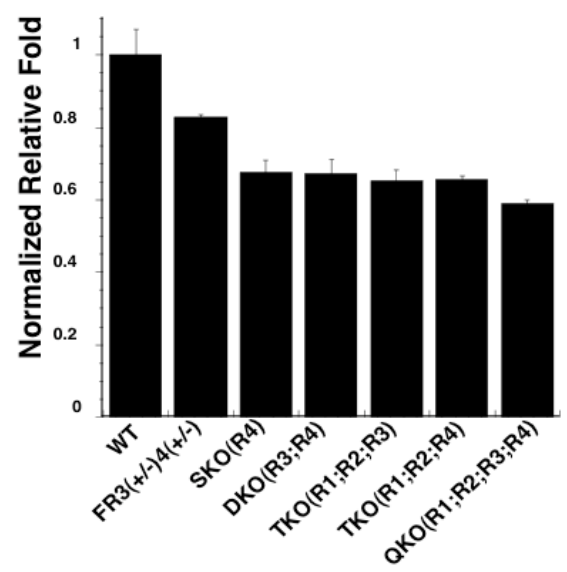

Rho

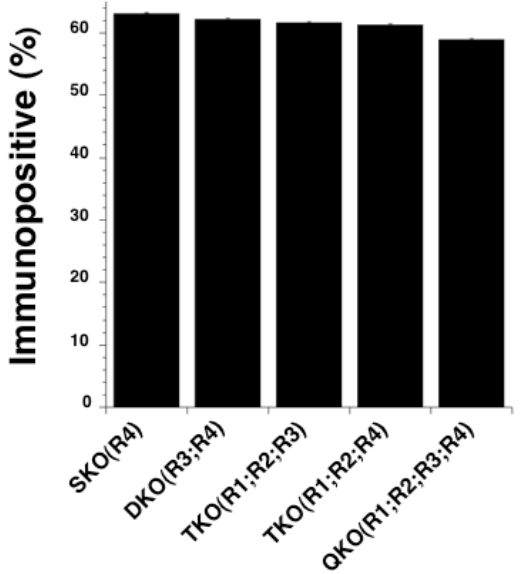

Figure 9. Analysis of a decrease in later born cell types in Fgf receptor deficient mice. (A) Real time RT-PCR for mice at stage P21 demonstrated a decrease for markers of later born cell types such as bipolar cells (PKCa) and Rod photoreceptors (Rho). (B) Dissociated cell scoring confirmed this observation with a decrease in PKCa and Rho. Abbreviations: P, Postnatal; Rho, Rhodopsin; SKO(R4), single knockout Fgfr4 ${ }^{-/-}$; DKO(R3;R4), double knockout $\mathrm{Fgfr}^{-/} ; \mathrm{Fgfr}^{-/-}$; TKO(R1;R2;R3), triple knockout Chx10-

Fgfr $^{\text {Lox/Lox }} ; \mathrm{Fgfr}^{\text {Lox/Lox }} ; \mathrm{Fgfr}^{-1-} ; \mathrm{Fgfr}^{+/-} ;$TKO(R1;R2;R4), triple knockout Chx10$\mathrm{Fgfr}^{\text {Lox/Lox; }} \mathrm{Fgfr}^{\text {Lox/Lox }} ; \mathrm{Fgfr}^{+/+} ; \mathrm{Fgfr}^{-1-} ;$ QKO(R1;R2;R3;R4), quadruple knockout

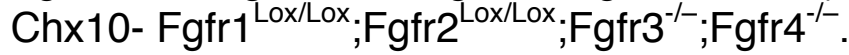


A

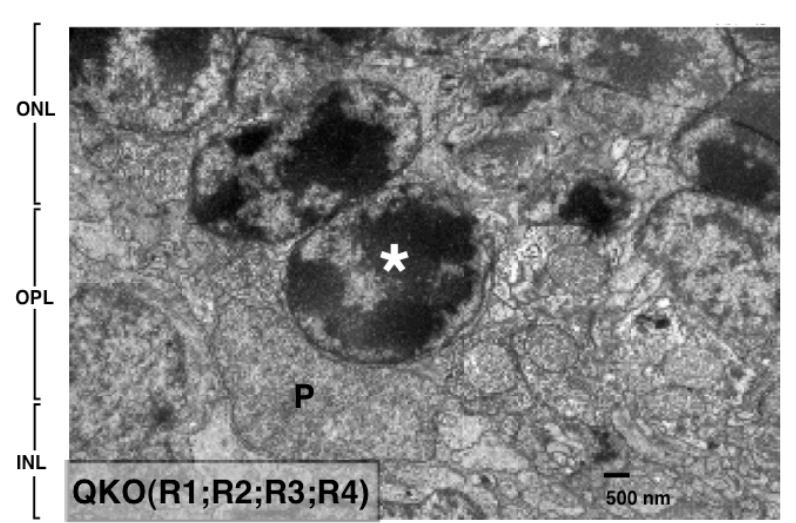

B

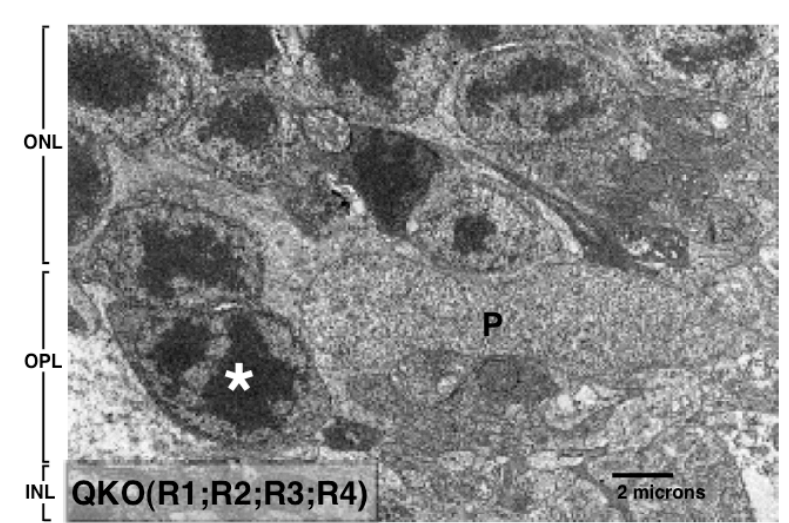

C

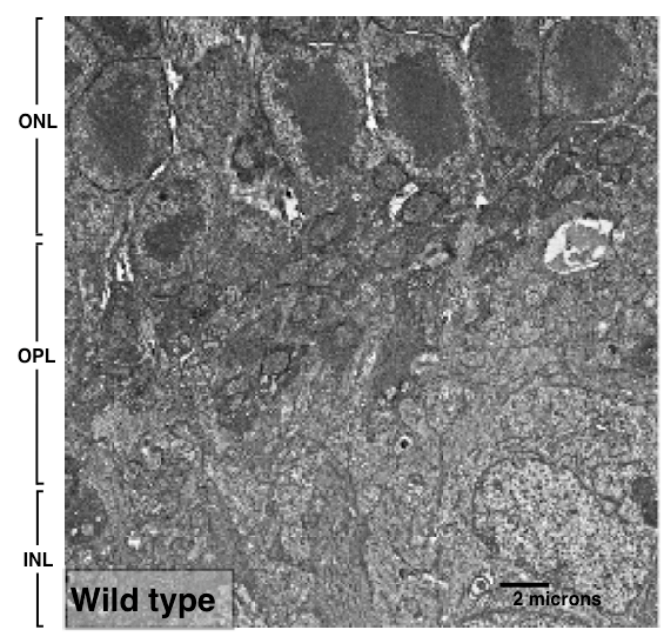

Figure 10. Analysis of abnormal OPL with the Fgfr mutant mice. (A-B) Analysis of Fgfr QKO mice at 4 weeks demonstrated a small OPL with displaced rod photoreceptors $\left(^{*}\right)$ as well as the appearance of progenitor like cells $(P)$. (C) $\mathrm{ONL}$, OPL, INL of a wild type retina. Abbreviations: ONL, outer nuclear layer; INL, inner nuclear layer; OPL, outer plexiform layer; QKO(R1;R2;R3;R4), quadruple knockout Chx10- Fgfr1 ${ }^{\text {Lox/Lox }} ; \mathrm{Fgfr}^{\text {Lox/Lox }}{ }^{\text {; }} \mathrm{Fgfr}^{-/-} ; \mathrm{Fgfr}^{-/-}{ }^{\text {. }}$. 
appeared within the retina of the quadruple knockout and the presence of an immature progenitor cell (Figure 10A-B).

\section{Visual acuity and intraocular pressure measurements of Fgfr knockout mice}

Based on our data suggesting that there may be a defect in photoreceptor development and outer plexiform layer (OPL) synaptogenesis I set out to test visual acuity in these mice using the Optomotry system (Douglas et al., 2005; Prusky et al., 2004). Visual acuity for Chx10-Cre;Fgfr $1^{\text {Lox/Lox }} ; \mathrm{Fgfr}^{\text {Lox/Lox }} ; \mathrm{Fgfr}^{-1-}$ mice was within the normal range of 3.5-4 cycles per degree (Figure 11). I tested 10 animals over the course of 5 days using this approach. The animals were a mixture of males and females and their age ranged from 6 to 7 weeks. The controls for optomotry were C57BI/6 mice and Aipl $1^{-/-}$mice. AIPL1 mice are phenotypically blind due to a genetic mutation that causes all photoreceptors to die early in development (Dyer et al., 2004; Ramamurthy et al., 2004). The Chx10-Cre;Fgfr ${ }^{\text {Lox/Lox }} ; \mathrm{Fgfr}^{\text {Lox/Lox }} ; \mathrm{Fgfr}^{-/-} ; \mathrm{Fgfr}^{-/-}$mice could not be analyzed by optomotry because they died around 4 weeks of age and older animals are required for Optomotry analysis.

To complement the Optomotry data we measured intraocular pressure using a rodent tonomoter. Tonomotry is based on impacting a very light plastic probe onto the cornea eye and measuring the force at which the probe recoils. Several measurements can be made on a daily basis over a relatively long periodof time. These experiments suggest that the retinal defects observed in the Chx10-Cre;Fgfr $1^{\text {Lox/Lox }} ; \mathrm{Fgfr}^{\text {Lox/Lox }} ; \mathrm{Fgfr}^{-/-}{ } ; \mathrm{Fgfr}^{-/-}$did not cause any change in intraocular pressure or secondary consequences on vision (Figure 12).

\section{Characterization of Fgf15-deficient retinae}

My preliminary data suggested that Fgf15 is the major FGF expressed in the embryonic retinal progenitor cells. Fgf15-deficient mice die embryonically between E12.5 and E13.5. 26.8\% of Fgf15 ${ }^{-/}$embryos are able to survive to E12.5, which is suitable for retinal explant cultures (Vincentz et al., 2005; Wright

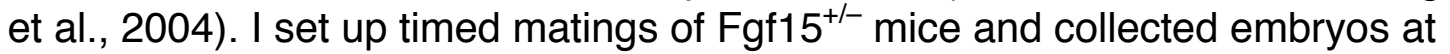
E12.5. Retinae from each embryo were cultured separately for 12 days to allow for complete retinal development. As with the Fgfr knockout retinae, I performed real time RT-PCR using Taqman probes for retinae from Fgf15 mutant explant cultures. Independent retinae were analyzed and all real time RT-PCR were performed in duplicate. I used probes specific for retinal cell types such as rods (Rhodopsin), cones (Cone Arrestin), photoreceptor cells (Revoverin), bipolar cells (PKC $\alpha$ ), Muller Glia (Glutamine Synthetase, GFAP), horizontal and amacrine 
Figure 11. Visual acuity appears to be normal in Fgfr KO mice. Optomotry for both SKO(R4) and TKO(R1,R2,R4) mice appeared to be normal when compared to a C57BL/6 mouse with cycles per degree in the correct ranges of 3.5-4c/d. The AIPL1 mouse is known to have visual impairment, as demonstrated by a visual acuity of $0 \mathrm{c} / \mathrm{d}$. Abbreviations: $\mathrm{c} / \mathrm{d}$ cycles per degree; SKO(R4), single knockout Fgfr4 $4^{-/}$; TKO(R1;R2;R4), triple knockout Chx10-

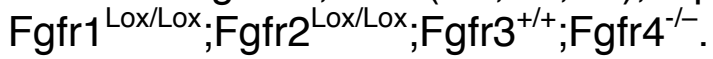


\begin{tabular}{|l}
\hline$\because-$ Left Eye \\
$\square-$ Right Eye
\end{tabular}

C57BL/6

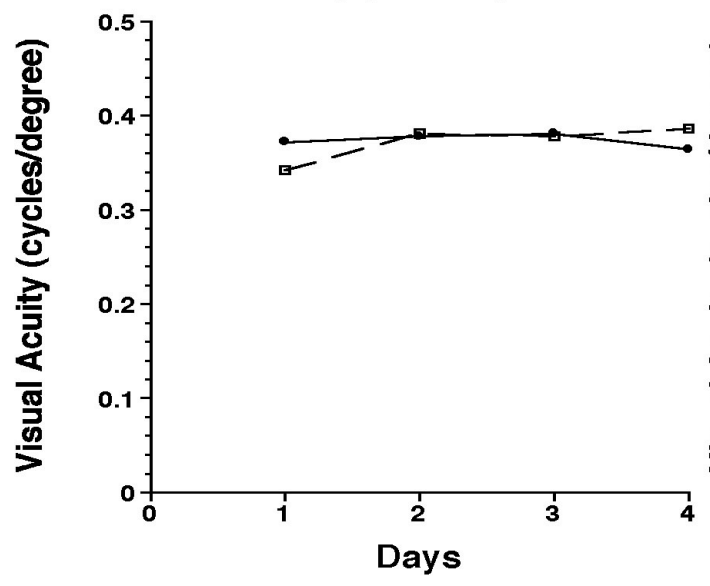

$\bullet-$ Left Eye
$\square-\mid$ Right Eye

AIPL1

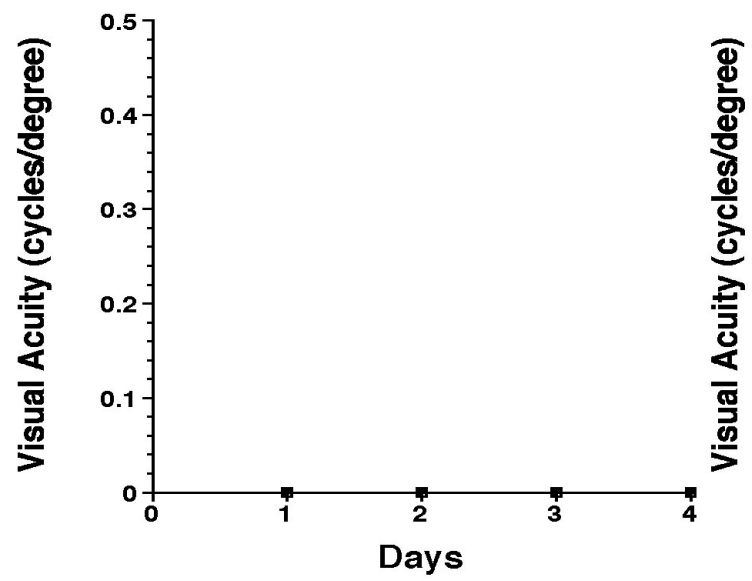

$\longrightarrow$ - Left Eye
$\square-$ Right Eye

SKO(R4)

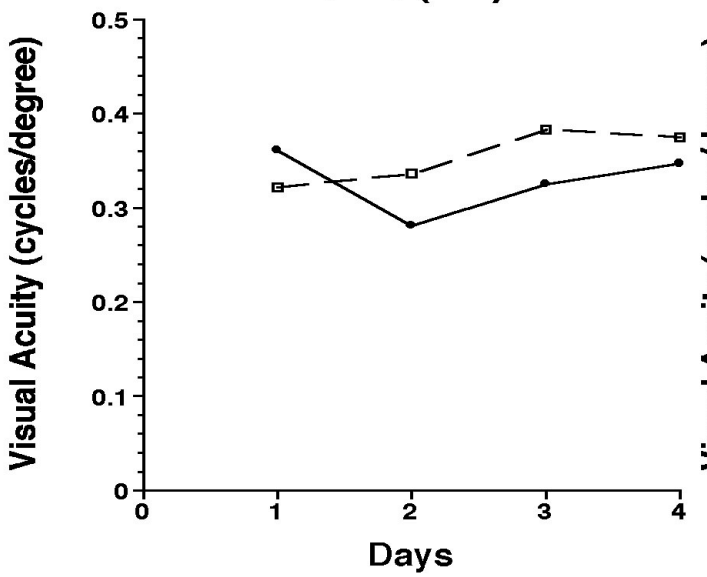

$\because \because-$ Left Eye

TKO(R1, R2, Ru) \begin{tabular}{l}
\hline$\dot{0}-$ Left Eye \\
\hline Right Eye
\end{tabular}

SKO(R4)

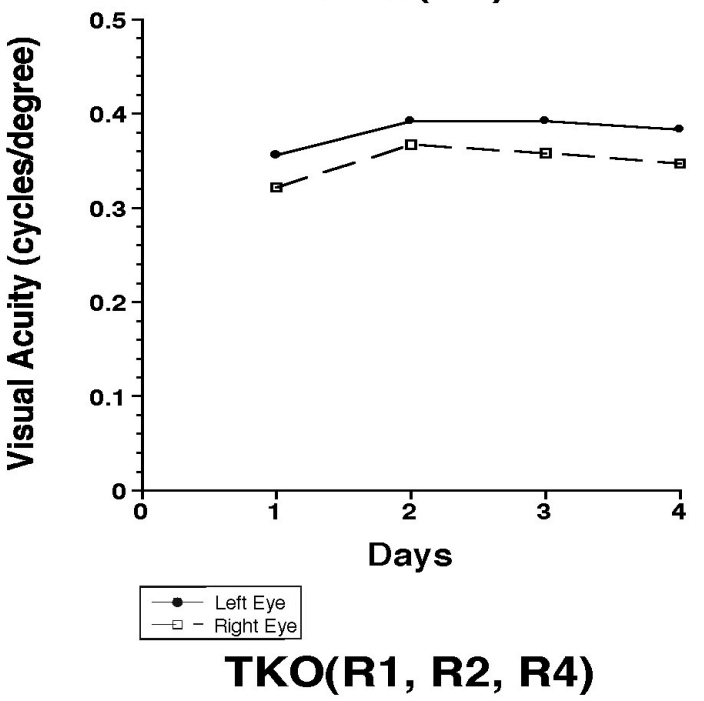

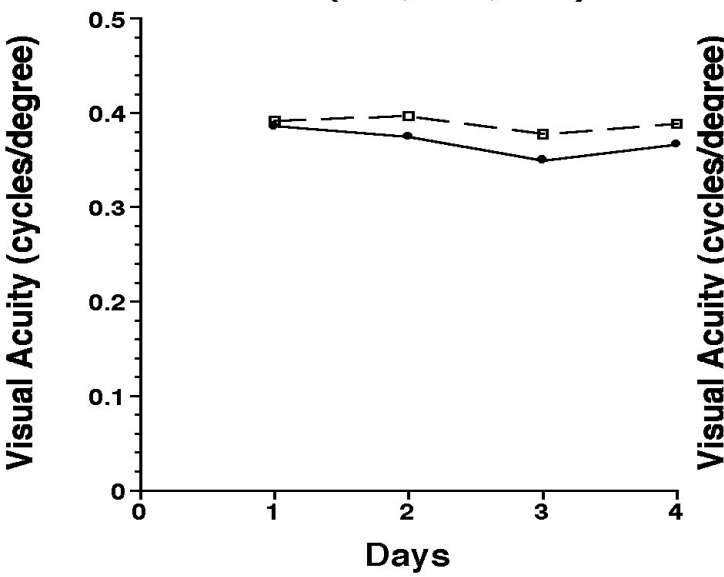

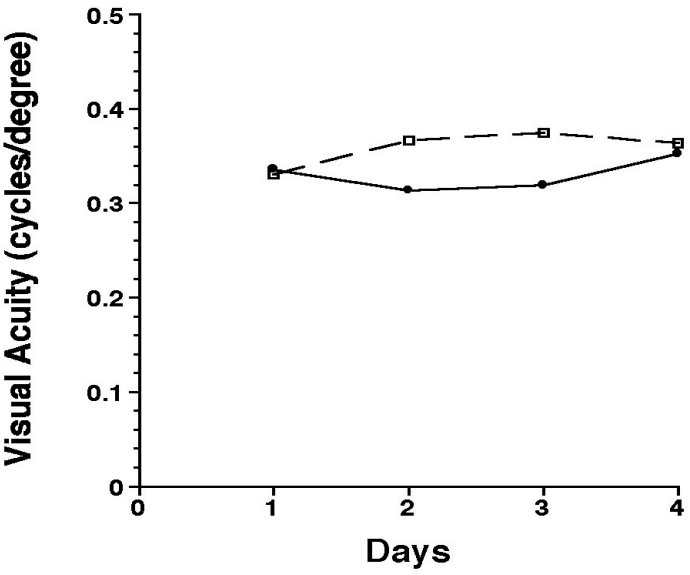

30 
Figure 12. Fgfr KO mice show normal ranges of intraocular pressure.

Tonomorty for both Fgfr SKO(R4) and TKO(R1,R2,R4) mice showed normal ranges of intraocular pressure as compared to $\mathrm{C} 57 \mathrm{BI} / 6$ and AIPL1 mice. Abbreviations: $\mathrm{SKO}(\mathrm{R} 4)$, single knockout Fgfr4 ${ }^{-/} ; \mathrm{TKO}(\mathrm{R} 1 ; \mathrm{R} 2 ; \mathrm{R} 4)$, triple

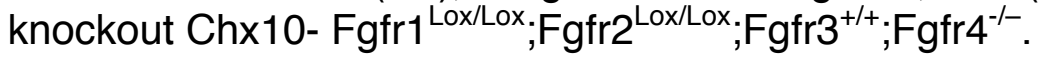



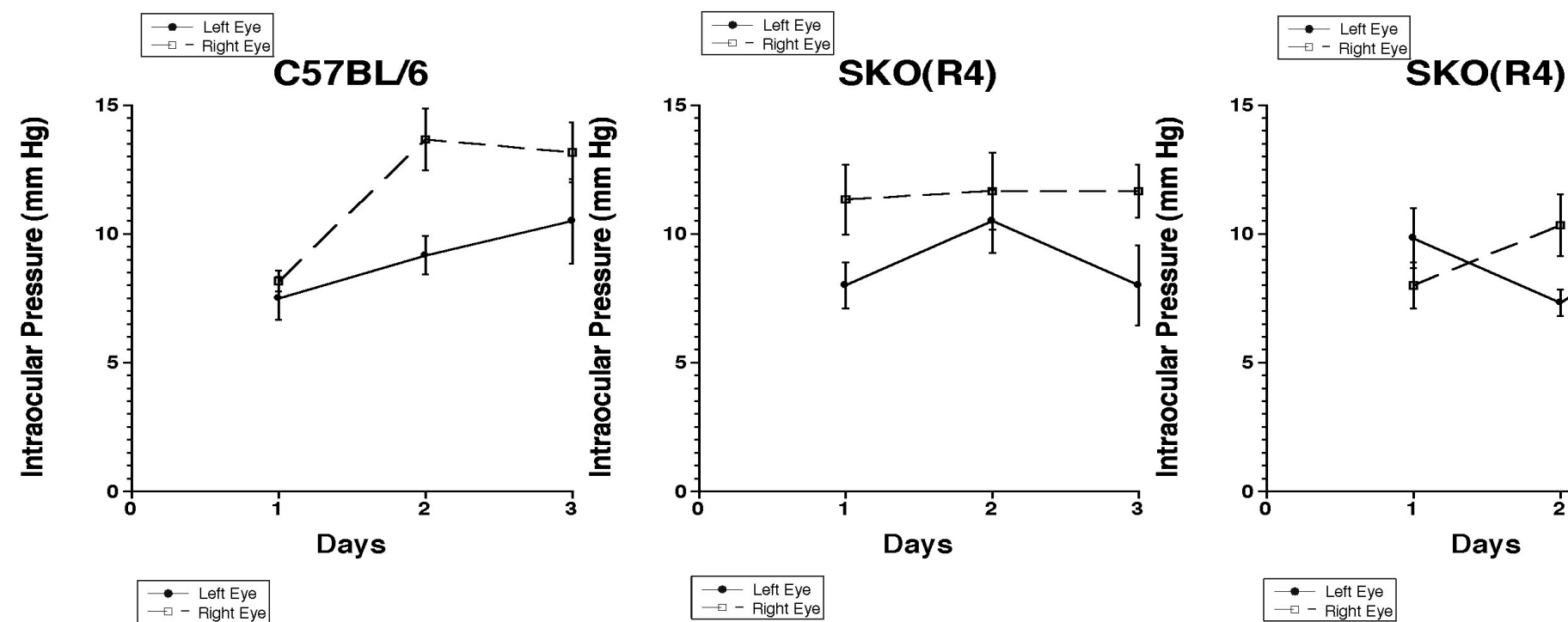

TKO(R1, R2, R4)

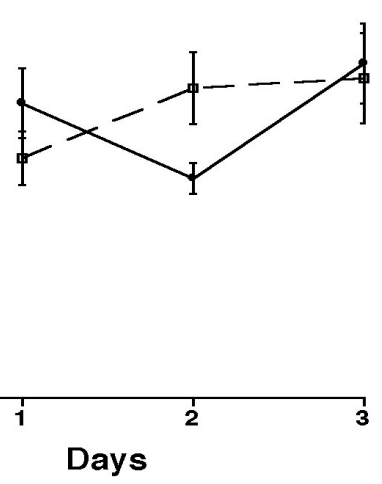

AIPL1
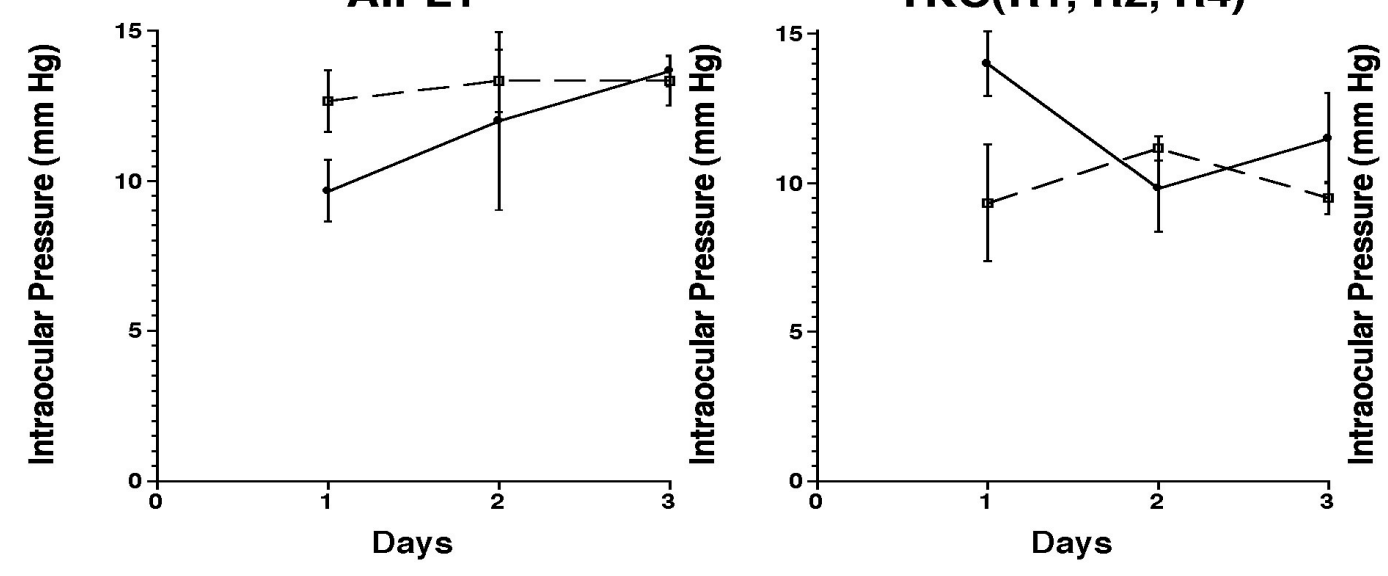

TKO(R1, R2, R4)

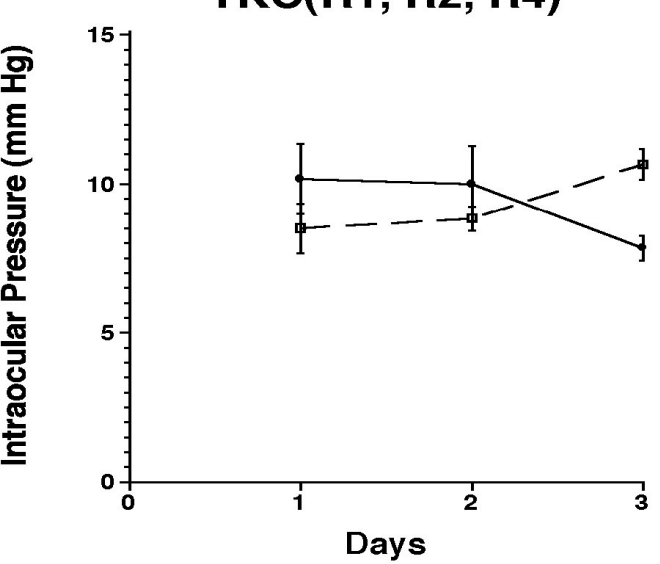


cells (Calbindin), as well as progenitor cells (Chx10, Pax6). An increase in Pax6 and Chx10 expression was observed via real time RT-PCR (Figure 13A). This increase in expression was observed in dissociated cells scoring for the Fgf15 explant cultures (Figure 13B). Immunostaining of cryosections of the explant cultures revealed that expression of $\mathrm{Ch} \times 10$ was not limited to mature bipolar cells and Pax6 was not limited to mature amacrine cells. Expression of these progenitor cell markers was throughout the entire retina and not localized to the mature retinal sub-types as seen in the control (data not shown). These three independent assays all revealed the persistence of expression for markers of retinal progenitor cells.

Along with an increase in progenitor expression, I also observed a decrease in markers of later born cell types such as rod photoreceptors and bipolar neurons. Through real time RT-PCR I observed a decrease in the mRNA expression of Rod photoreceptors (Rho), and Bipolar cells (PKC $\alpha$ ) (Figure 14A). This was further verified by dissociated cell scoring of the markers Rhodopsin and PKC $\alpha$ (Figure 14B-C).

In the absence of Fgf15, real time RT-PCR also did not reveal a significant change in the expression of Fgfr2, Fgfr4 and Fgfrl-1. However, there was a noticeable increase in the expression of Fgfr 1 in the absence of Fgf15 suggesting regulation of a feedback loop (Figure 15A-D). Through real time RT-PCR I also detected a very slight increase in the expression of other Fgf's such as Fgf10, Fgf12, and Fgf13 (Figure 15E-G). This feedback by FGF signaling molecules and their receptors in response to the absence of Fgf15 further suggests the importance of regulation of this extrinsic factor. 

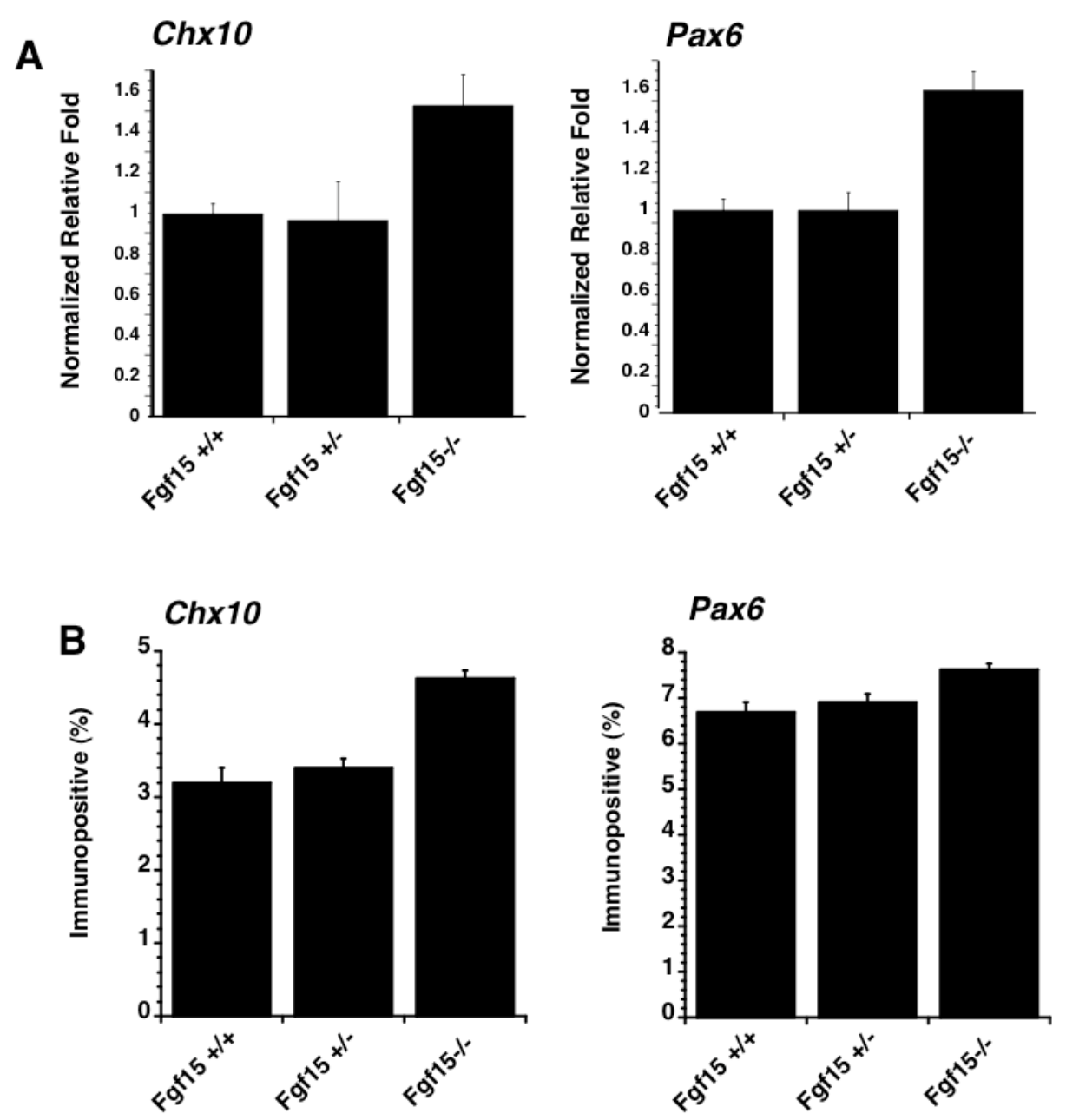

Figure 13. Analysis of the presence of persistent progenitor cell markers in Fgf15 explant cultures. (A) Real time RT-PCR demonstrated an increase in expression of progenitor cell markers Chx10 and Pax6 in Fgf15 mutant mice when normalized to Fgf15 wild type mice. (B) Dissociated cell scoring revealed a similar decrease in progenitor expression for Chx10 and Pax6. 
A

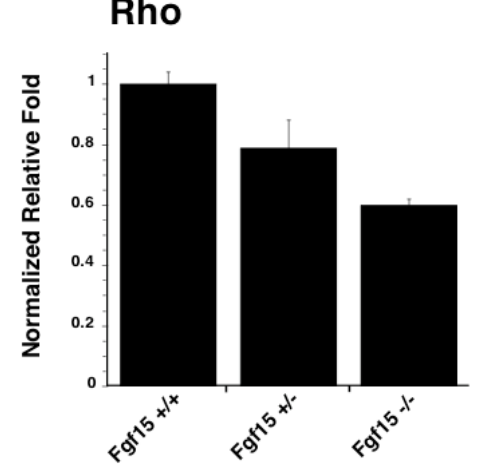

B
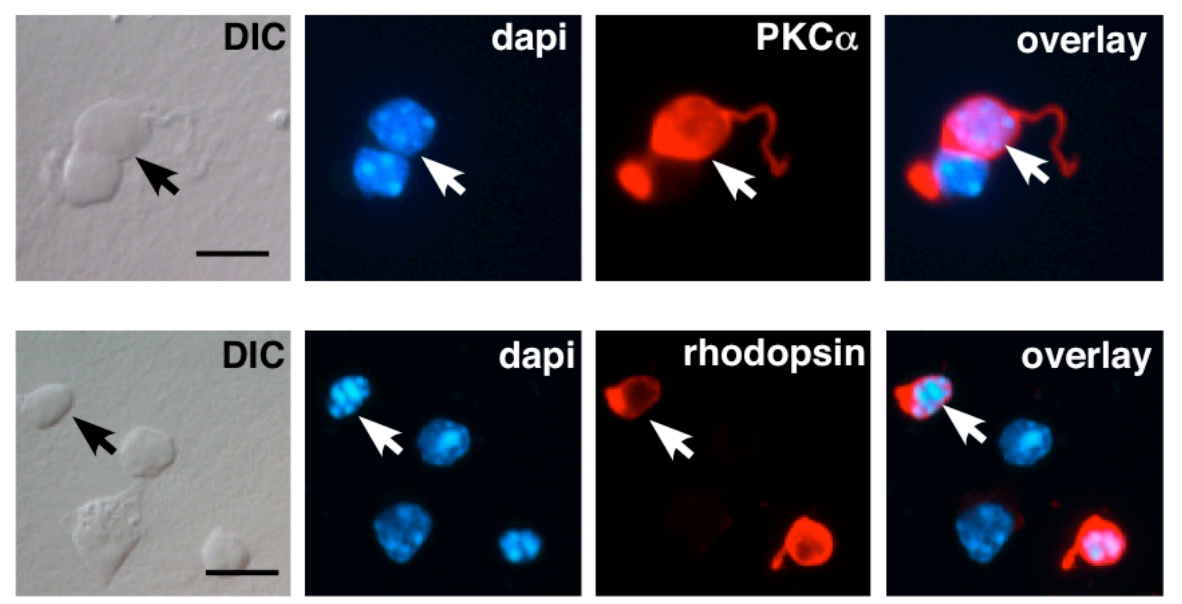

C
PKCa

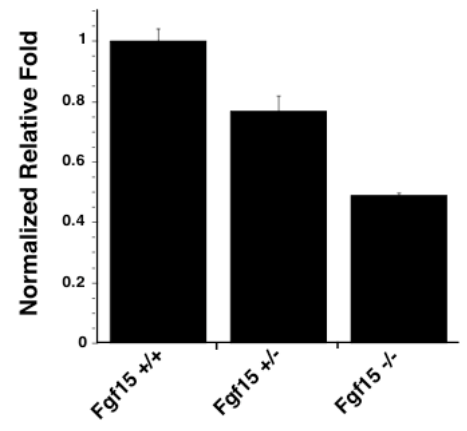

Rho

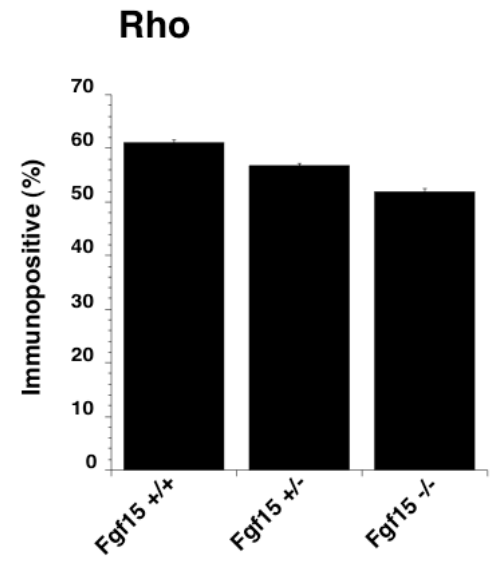

(1)

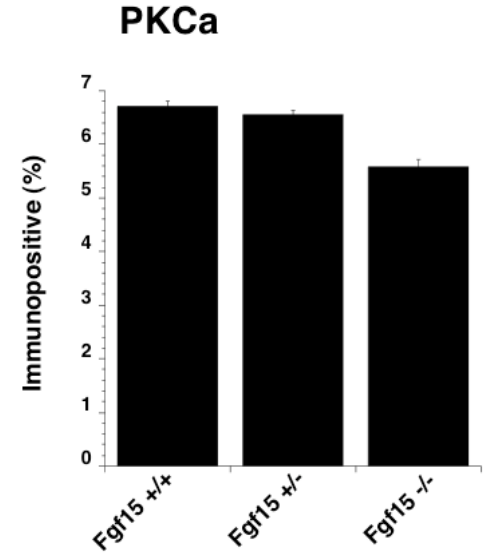

Figure 14. Analysis of a decrease in later born cell types in Fgf15 explant cultures. (A) Real time RT-PCR demonstrated a decrease for markers of later born cell types such as rod photoreceptors (Rho) and bipolar cells (PKCa). (B-C) Dissociated Cell Scoring confirmed this observation with a decrease in PKCa. Abbreviations: Rho, Rhodopsin. 

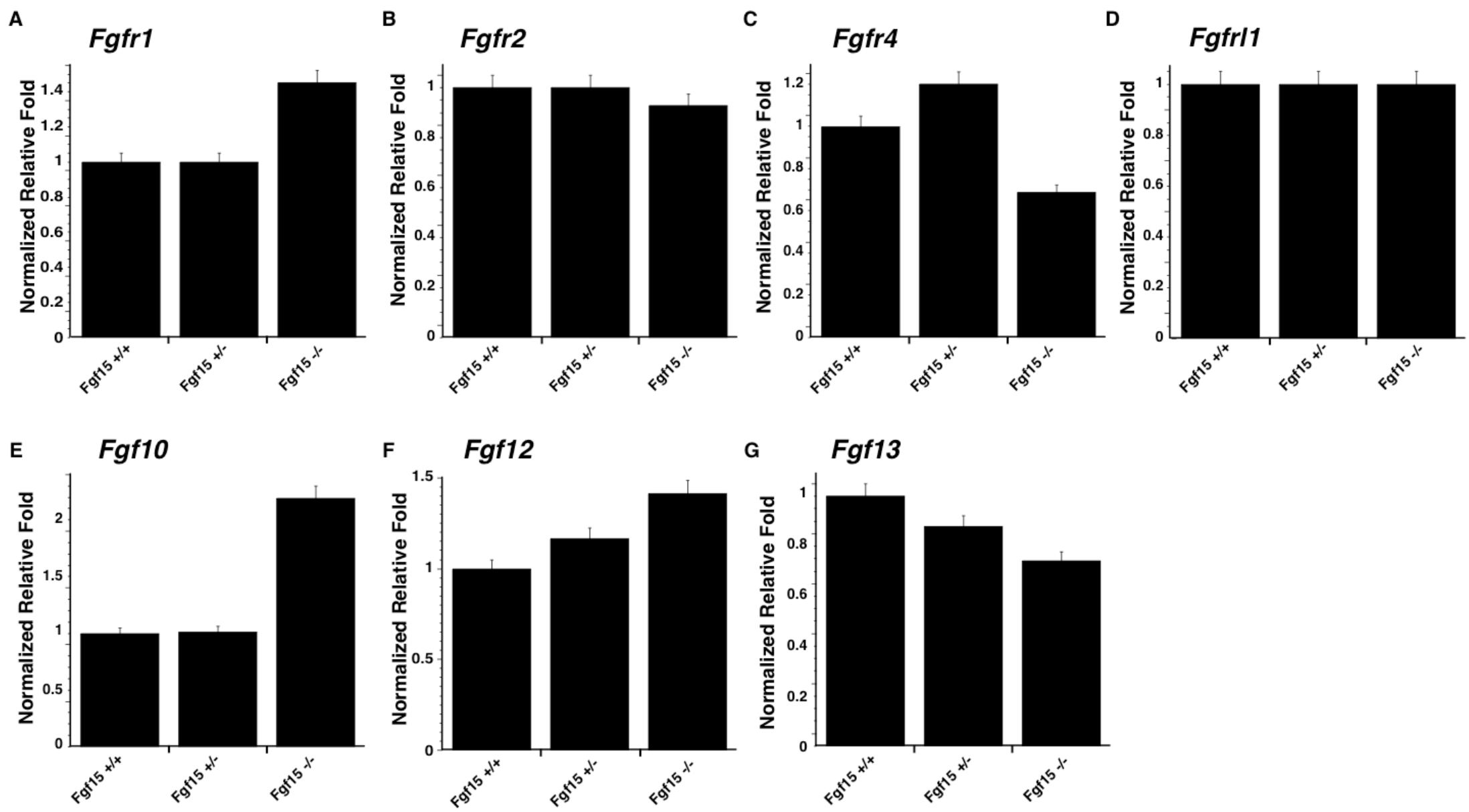

Figure 15. Analysis of Fgf and Fgf receptor expression in Fgf15 explant cultures. (B-C) There did not appear to be a significant change in the mRNA expression levels of Fgfr2, Fgfr4 and Fgfrl1 in Fgf15 deficient mice. (A) A two-fold increase in Fgfr1 was detected in the Fgf15 deficient mice. (E-G) There appeared to be an increase in the expression of other Fgfs within the developing retina in the absence of Fgf15. 


\section{CHAPTER IV. DISCUSSION}

Fgf15 is a good candidate for an extrinsic factor that may regulate retinal progenitor cell proliferation in the developing retina. Through SAGE database analysis and real time RT-PCR we were able to analyze the mRNA expression pattern of Fgfs and Fgfrs within the developing retina. It is particularly interesting that Fgf15 is expressed at such high levels in the embryonic retina but is absent in postnatal retinal progenitor cells. For example, the levels of Fgf15 drop by nearly 1,000 fold from E14 to P0 as measured by real time RT-PCR using taqman probes. In addition with the use of in situ hybridization we were able to observe that the localization of Fgf15 within the developing retina was within the ONBL where progenitor cells are rapidly dividing and not in the INBL where postmitotic cells reside. This suggests that there is heterogeneity of retinal progenitor cells in the developing mouse retina. Fgf15 is expressed in most if not all embryonic retinal progenitor cells but is absent from postnatal retinal progenitor cells.

The Fgf receptor gene expression was somewhat more complex than that of Fgf15. Fgfr1 was expressed at the highest levels and was enriched at embryonic stages as compared to postnatal stages but this was only a small difference. The other Fgfr genes were expressed at several different stages in retinal development and in the adult retina. In situ hybridization was not particularly useful for these genes because they were expressed at low levels in the developing retina making it difficult to distinguish between specific hybridization signal and non-specfiic background staining. Despite these limitations, our data does suggest that the Fgfr genes are expressed in both mitotic and postmitotic cells in the developing retina. Immunostaining for the Fgfr proteins was carried out using antibodies that had been previously characterized. However, we were unable to detect specific immnofluorescence even when we used a variety of antigen retrieval procedures. Again, we believe this is due to the low level of expression of the Fgfr genes in the developing retina.

In order to test the role of Fgf signaling in retinal development, I characterized the retinae from mice lacking Fgf15 or mice lacking all 4 Fgfr genes. From our preliminary studies data from these two approaches were very similar suggesting that the major Fgf in the retina is Fgf15. We found that in the absence of Fgf signaling, retinal progenitor cells persisted into the adult stage when retinogenesis is normally complete. These cells were identified by their expression of progenitor cell genes and their morphology in TEM images. In addition, we noted a decrease in late born cell types (rods, bipolar cells and Muller glia). When combined with the expression data, these findings suggest that in the absence of Fgf signaling, retinal progenitor cells fail to complete their normal developmental program. This may reflect a slowing of the cell cycle in 
retinal progenitor cells or a failure to exit the cell cycle at the appropriate stages of development. A series of experiments are in progress to test these hypotheses. 


\section{CHAPTER V. FUTURE DIRECTIONS}

My preliminary data suggest that in the absence of FGF signaling, retinal progenitor cells persist late in retinogenesis and thus there is a reduction in the production of late born cell types. There was no dramatic hyperplasia in the retinae with reduced FGF signaling. Taking these observations together, I propose that in the absence of FGF signaling, retinal progenitor cell proliferation is slower and this may account for the persistent progenitor cells as well as the reduction in late born cell types. To test this hypothesis, it is important to characterize the proportion of proliferating cells throughout development in both the Fgf15-deficient retinae as well as the Fgfr-deficient retinae. These approaches are complementary in that the Fgfr knockout retinae lack all canonical Fgf signaling while the Fgf15 knockout provides insight into the specific role of this particular FGF. Thus far, the phenotype of the Fgf15 and Fgfr knockout retinae are similar, suggesting that the major FGF signaling pathway in the retina is through Fgf15. If my prediction is correct, and the absence of FGF signaling only affects the length of the cell cycle then one might observe relatively normal proportion of BrdU+ cells from a pulse labeling experiment at early stages of development. However, as development progresses and the proportion of dividing cells decreases in the normal retina, there may be a proportional increase in the percentage of BrdU+cells in the retinae lacking Fgf signaling. More importantly, I would predict that experiments to measure cell cycle length should show a longer cell cycle in the FGF-signaling deficient retinae.

Experiments should also be performed at each stage of development to rule out cell death as a contributing factor in the phenotype that I have characterized. At 2 and 3 weeks of age there was no difference in cell death in any of the mice studied but a more comprehensive analysis of all developmental stages in warranted. Experiments should also be performed using Fgfr inhibitors such as SU 5420 to block Fgf signaling within the developing retina and assess the consequences of the loss of Fgf signaling (Mohammadi et al., 1997).

Another interesting possibility is that FGF signaling is important for the transition from a mode of cell division that produces more progenitor cells to a reductive cell division pattern. Specifically, in the embryonic retina when Fgf15 is expressed, each progenitor cell division is producing more progenitor cells as a population and only a small minority of cells exit the cell cycle to differentiate as neurons. However, precisely at the time that Fgf15 expression is extinguished, the pattern of cell division changes to reductive form that produces primarily postmitotic cells. In the absence of FGF signaling, this pattern may be perturbed leading to an overall reduction in progenitor cells and the total cell number in the retinae would be reduced. This would be most pronounced in the reduction of photoreceptors and late born cell types as we have observed here. To test this 
hypothesis, lineage analysis should be carried out to study the size and composition of clones in the retinae lacking Fgf15 and Fgfr gene function. Ideally, a Cre expressing retrovirus could be used in vivo to study the clonal composition in $\mathrm{Fgfr}_{1}{ }^{\text {Lox/Lox }} ; \mathrm{Fgfr}^{\mathrm{Lox} / \mathrm{Lox}} ; \mathrm{Fgfr}^{-/-} ; \mathrm{Fgfr}^{-/-}$mice to elucidate the cell autonomous role of FGF signaling in the pattern of retinal progenitor cell proliferation, cell fate specification and differentiation. 


\section{LIST OF REFERENCES}

Arman, E., Haffner-Krausz, R., Chen, Y., Heath, J. K. and Lonai, P. (1998). Targeted disruption of fibroblast growth factor (FGF) receptor 2 suggests a role for FGF signaling in pregastrulation mammalian development. Proc Natl Acad Sci U S A 95, 5082-7.

Blackshaw, S., Harpavat, S., Trimarchi, J., Cai, L., Huang, H., Kuo, W. P., Weber, G., Lee, K., Fraioli, R. E., Cho, S. H. et al. (2004). Genomic analysis of mouse retinal development. PLoS Biol 2, E247.

Cepko, C. L., Austin, C. P., Yang, X., Alexiades, M. and Ezzeddine, D. (1996). Cell fate determination in the vertebrate retina. Proc Natl Acad Sci U S A 93, 58995.

Colvin, J. S., Bohne, B. A., Harding, G. W., McEwen, D. G. and Ornitz, D. M. (1996). Skeletal overgrowth and deafness in mice lacking fibroblast growth factor receptor 3. Nat Genet 12, 390-7.

Dakubo, G. D., Wang, Y. P., Mazerolle, C., Campsall, K., McMahon, A. P. and Wallace, V. A. (2003). Retinal ganglion cell-derived sonic hedgehog signaling is required for optic disc and stalk neuroepithelial cell development. Development 130, 2967-80.

Danias, J., Kontiola, A. I., Filippopoulos, T. and Mittag, T. (2003). Method for the noninvasive measurement of intraocular pressure in mice. Invest Ophthalmol Vis Sci 44, 1138-41.

Deng, C., Bedford, M., Li, C., Xu, X., Yang, X., Dunmore, J. and Leder, P. (1997). Fibroblast growth factor receptor-1 (FGFR-1) is essential for normal neural tube and limb development. Dev Biol 185, 42-54.

Deng, C., Wynshaw-Boris, A., Zhou, F., Kuo, A. and Leder, P. (1996). Fibroblast growth factor receptor 3 is a negative regulator of bone growth. Cell 84, 911-21.

Deng, C. X., Wynshaw-Boris, A., Shen, M. M., Daugherty, C., Ornitz, D. M. and Leder, P. (1994). Murine FGFR-1 is required for early postimplantation growth and axial organization. Genes Dev 8, 3045-57. 
Douglas, R. M., Alam, N. M., Silver, B. D., McGill, T. J., Tschetter, W. W. and Prusky, G. T. (2005). Independent visual threshold measurements in the two eyes of freely moving rats and mice using a virtual-reality optokinetic system. Vis Neurosci 22, 677-84.

Dyer, M. A. and Cepko, C. L. (2000). Control of Muller glial cell proliferation and activation following retinal injury. Nat Neurosci 3, 873-80.

Dyer, M. A., Donovan, S. L., Zhang, J., Gray, J., Ortiz, A., Tenney, R., Kong, J., Allikmets, R. and Sohocki, M. M. (2004). Retinal degeneration in Aipl1deficient mice: a new genetic model of Leber congenital amaurosis. Brain Res Mol Brain Res 132, 208-20.

Ezzeddine, Z. D., Yang, X., DeChiara, T., Yancopoulos, G. and Cepko, C. L. (1997). Postmitotic cells fated to become rod photoreceptors can be respecified by CNTF treatment of the retina. Development 124, 1055-67.

Jeon, C. J., Strettoi, E. and Masland, R. H. (1998). The major cell populations of the mouse retina. J Neurosci 18, 8936-46.

Livesey, F. J. and Cepko, C. L. (2001). Vertebrate neural cell-fate determination: lessons from the retina. Nat Rev Neurosci 2, 109-18.

Masland, R. H. (2001). Neuronal diversity in the retina. Curr Opin Neurobiol 11, 431-6.

Mohammadi, M., McMahon, G., Sun, L., Tang, C., Hirth, P., Yeh, B. K., Hubbard, S. R. and Schlessinger, J. (1997). Structures of the tyrosine kinase domain of fibroblast growth factor receptor in complex with inhibitors. Science 276, 955-60.

Molday, R. S. and MacKenzie, D. (1983). Monoclonal antibodies to rhodopsin: characterization, cross-reactivity, and application as structural probes.

Biochemistry 22, 653-60.

Ornitz, D. M. (2000). FGFs, heparan sulfate and FGFRs: complex interactions essential for development. Bioessays 22, 108-12.

Ornitz, D. M. and Itoh, N. (2001). Fibroblast growth factors. Genome Biol 2, REVIEWS3005.

Pirvola, U., Ylikoski, J., Trokovic, R., Hebert, J. M., McConnell, S. K. and Partanen, J. (2002). FGFR1 is required for the development of the auditory sensory epithelium. Neuron 35, 671-80. 
Plotnikov, A. N., Schlessinger, J., Hubbard, S. R. and Mohammadi, M. (1999). Structural basis for FGF receptor dimerization and activation. Cell 98, 641-50.

Powers, C. J., McLeskey, S. W. and Wellstein, A. (2000). Fibroblast growth factors, their receptors and signaling. Endocr Relat Cancer 7, 165-97.

Prusky, G. T., Alam, N. M., Beekman, S. and Douglas, R. M. (2004). Rapid quantification of adult and developing mouse spatial vision using a virtual optomotor system. Invest Ophthalmol Vis Sci 45, 4611-6.

Purves, D. (2004). Neuroscience. In Sensation and Sensory Processing, (ed. D. Fitzpatrick). Sunderland, MA: Sinauer Associates, Inc.

Ramamurthy, V., Niemi, G. A., Reh, T. A. and Hurley, J. B. (2004). Leber congenital amaurosis linked to AIPL1: a mouse model reveals destabilization of cGMP phosphodiesterase. Proc Natl Acad Sci U S A 101, 13897-902.

Sernagor E., E. S., Harris B., Wong Rachel. (2006). Retinal Development. New York: Cambridge University Press.

Trokovic, R., Trokovic, N., Hernesniemi, S., Pirvola, U., Vogt Weisenhorn, D. M., Rossant, J., McMahon, A. P., Wurst, W. and Partanen, J. (2003). FGFR1 is independently required in both developing mid- and hindbrain for sustained response to isthmic signals. Embo J 22, 1811-23.

Vincentz, J. W., McWhirter, J. R., Murre, C., Baldini, A. and Furuta, Y. (2005). Fgf15 is required for proper morphogenesis of the mouse cardiac outflow tract. Genesis 41, 192-201.

Wassle, H. (2004). Parallel processing in the mammalian retina. Nat Rev Neurosci 5, 747-57.

Weinstein, M., Xu, X., Ohyama, K. and Deng, C. X. (1998). FGFR-3 and FGFR-4 function cooperatively to direct alveogenesis in the murine lung. Development 125, 3615-23.

Wiedemann, M. and Trueb, B. (2000). Characterization of a novel protein (FGFRL1) from human cartilage related to FGF receptors. Genomics 69, 275-9.

Wright, T. J., Ladher, R., McWhirter, J., Murre, C., Schoenwolf, G. C. and Mansour, S. L. (2004). Mouse FGF15 is the ortholog of human and chick FGF19, but is not uniquely required for otic induction. Dev Biol 269, 264-75. 
Xu, X., Qiao, W., Li, C. and Deng, C. X. (2002). Generation of Fgfr1 conditional knockout mice. Genesis 32, 85-6.

Yamaguchi, T. P., Harpal, K., Henkemeyer, M. and Rossant, J. (1994). fgfr-1 is required for embryonic growth and mesodermal patterning during mouse gastrulation. Genes Dev 8, 3032-44.

Young, R. W. (1985). Cell proliferation during postnatal development of the retina in the mouse. Brain Res 353, 229-39.

Yu, C., Wang, F., Kan, M., Jin, C., Jones, R. B., Weinstein, M., Deng, C. X. and McKeehan, W. L. (2000). Elevated cholesterol metabolism and bile acid synthesis in mice lacking membrane tyrosine kinase receptor FGFR4. J Biol Chem 275, 15482-9.

Yu, K., Xu, J., Liu, Z., Sosic, D., Shao, J., Olson, E. N., Towler, D. A. and Ornitz, D. M. (2003). Conditional inactivation of FGF receptor 2 reveals an essential role for FGF signaling in the regulation of osteoblast function and bone growth. Development 130, 3063-74. 


\section{APPENDIX: CHAPTER III SUPPLEMENTARY INFORMATION}
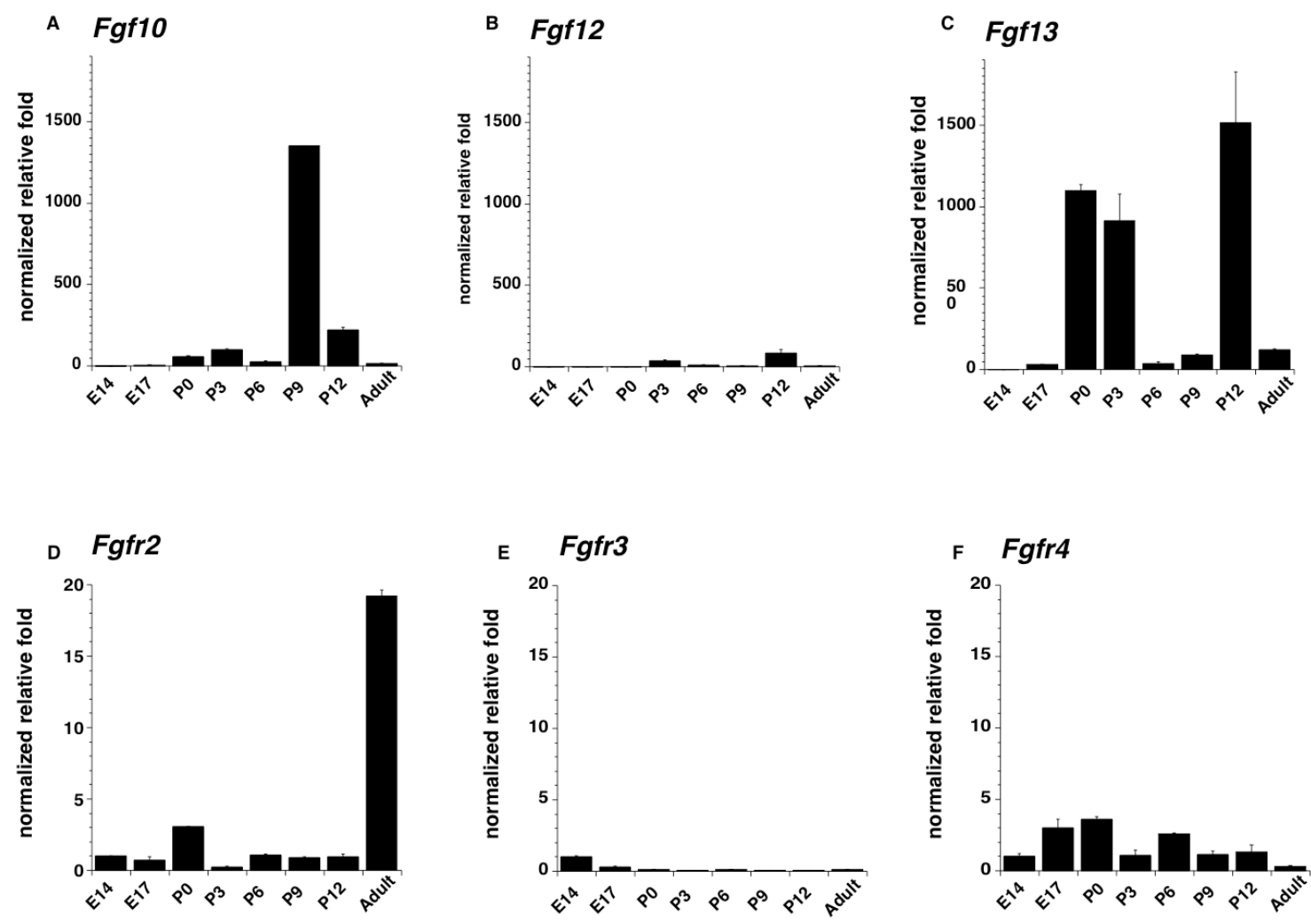

Figure A-1. Real time RT-PCR analysis of Fgf10, Fgf12 and Fgf13. Real time RT-PCR was performed for 8 stages of retinal development and data were normalized to internal controls (Gapdh or Gpi1). Relative fold was plotted by setting E14.5 levels to 1.0. (A-C) mRNA expression of Fgf10, Fgf12 and Fgf13 appeared to be at higher levels during later stages of development. (D-F) While the real time RT-PCR probes detected Fgfr2-4 in the developing retina, it was not clear weather this expression is at levels sufficient to be biologically relevant. Abbreviations: E, Embryonic; P, Postnatal. 
A

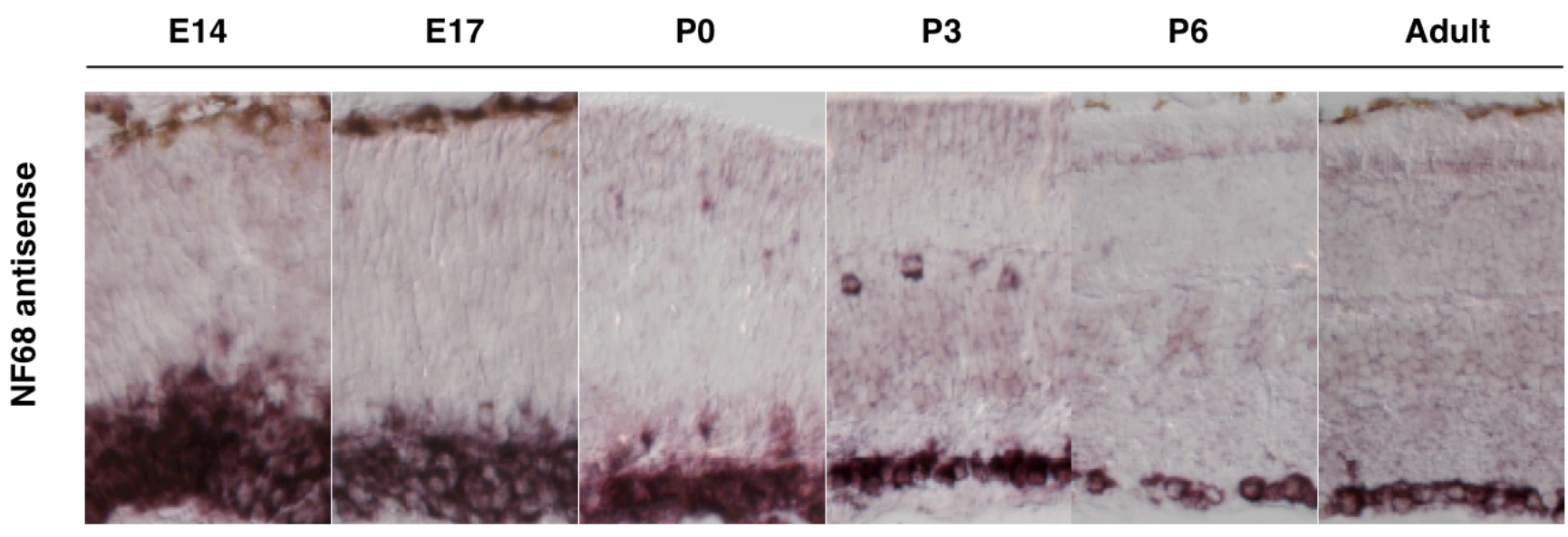

B

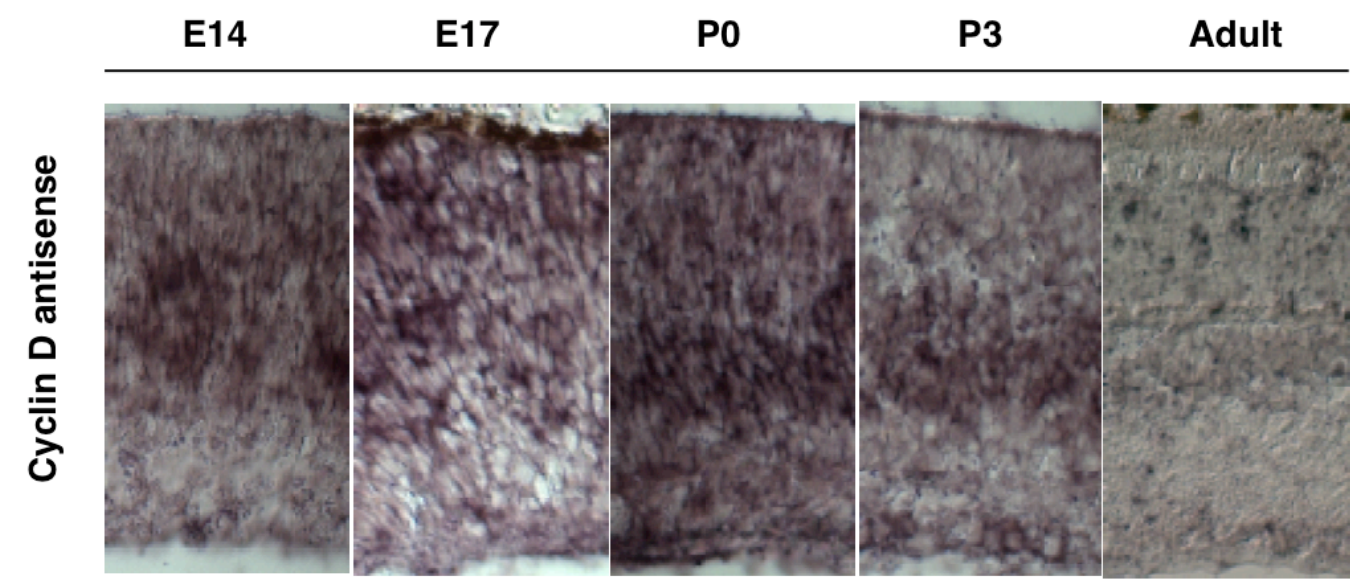

Figure A-2. In situ hybridization of NF68 and Cyclin D1 in the developing mouse retina. As a positive control an antisense probe to NF68 that labels developing ganglion cells and Cyclin D1 which labels actively proliferating cells were used. (A) Specific hybridization signal of NF68 in the developing retina. (B) Specific hybridization signal of Cyclin D1within the developing retina. Abbreviations: E, Embryonic; P, Postnatal. 


\section{VITA}

Abbie A. Hartge was born October 10, 1983 in Columbus, Ohio. She attended Ohio University where she received a Bachelor of Specialized Studies degree in Women's Reproductive Health and minored in Chemistry in 2005. Immediately following she joined the Integrated Program of Biomedical Studies (IPBS) at The University of Tennessee Health Science Center. She began her research studies in the lab or Dr. Michael A Dyer at St. Jude Children's Research Hospital in the summer of 2006. Her committee members included Dr. Dianna A. Johnson Ph.D., Dr. Peter J. McKinnon Ph.D., Dr. Martine Roussel Ph.D. and Dr. Beatriz Sosa-Pineda. Abbie expects to receive her Master of Science degree in Cancer and Developmental Biology in December of 2008. 